\title{
Extraterritoriality as Choice of Law
}

Carlos Manuel Vázquez

Georgetown University Law Center, vazquez@law.georgetown.edu

This paper can be downloaded free of charge from:

https://scholarship.law.georgetown.edu/facpub/2280

https://ssrn.com/abstract=3618080

This open-access article is brought to you by the Georgetown Law Library. Posted with permission of the author. Follow this and additional works at: https://scholarship.law.georgetown.edu/facpub

Part of the Civil Procedure Commons, Comparative and Foreign Law Commons, Jurisprudence Commons, and the Litigation Commons 


\section{EXTRATERRITORIALITY AS CHOICE OF LAW}

\section{Carlos M. Vázquez}

The proper treatment of provisions that specify the territorial scope of statutes has long been a matter of controversy in Conflict of Laws scholarship. This issue is of considerable current interest because the draft Third Restatement of Conflict of Laws proposes to address such provisions in a way that diverges from how they were treated in the Second Restatement. The Second Restatement treats such provisions - which I call geographic scope limitationsas choice-of-law rules, meaning, inter alia, that the courts will ordinarily disregard them when the forum's choice-of-law rules or a contractual choice-of-law clause selects the law of a state as the governing law. The Third Restatement does not consider them to be choice-of-law rules, viewing them instead as inextricable parts of a state's substantive law. This means, according to the Third Restatement, that contractual choice-of-law clauses are presumed to select the chosen state's law subject to their geographic scope limitations, and that the courts of other states are obligated to give effect to such limits when their choice-of-law rules direct application of that state's law. Indeed, according to the Third Restatement, failure to do so would violate the obligation of U.S. states to give Full Faith and Credit to the laws of sister states.

This article defends the Second Restatement's understanding of geographic scope limitations as choice-of-law rules. Limits on a statute's territorial scope are fundamentally different from limits on a statute's internal scope. When a state enacts a statute and specifies that it applies only to conduct occurring within the state's territory, or to residents of the state, it has limited the reach of the law out of deference to the legislative authority of other states. The state does not have a different rule for non-residents or for conduct that occurs on the territory of other states. The territorial scope provision tells us only that cases beyond the statute's specified scope should be governed by the law of a different state.

The Third Restatement treats geographic scope limitations as prescribing non-regulation for cases beyond the statute's specified geographic scope. This understanding of geographic scope limitations is highly implausible and, indeed, either unconstitutionally discriminatory or unconstitutionally arbitrary. Failure to give effect to such provisions does not violate the Full Faith and Credit Clause. To the contrary, such provisions violate the Full Faith and Credit Clause. Understood as choice-of-law rules, geographic scope limitations are binding on the courts of the enacting state, and other states may take them into account in determining whether to apply the law of the enacting state. But, if the forum's choice-of-law rules select the law of

* Scott K. Ginsburg Professor of Law, Georgetown University Law Center. I am grateful for helpful comments from and discussions with Eduardo Alvarez Armas, Lea Brilmayer, Hannah Buxbaum, Brian Galle, Gregory Klass, David Luban, Alex Mills, Paul Rothstein, Michael Seidman, Larry Solum, Symeon Symeonides, and Horatia Muir Watt. I also very much appreciate Kermit Roosevelt's extended engagement with me on these issues, as reflected in correspondence cited below. I am also grateful for very helpful research assistance by Yukihiko Segawa and Wei Zhang. 
the enacting state as the governing law, the constitutional obligation of U.S. states to respect the laws of their sister states poses no impediment to application of the statute's substantive provisions to cases beyond the statute's specified geographic scope.

How to understand statutory provisions specifying the territorial scope of laws has long been a matter of debate among Conflict of Laws scholars. Such provisions address the extent to which the statute reaches cases having foreign elements. They specify the applicability of the law by reference to the existence of some connection between the dispute and the enacting state. ${ }^{1}$ For example, a statute may specify that it applies to conduct taking place within the enacting state's territory or to persons domiciled in the state. I will call these geographic scope provisions. They have received considerable scholarly attention outside the United States but have largely escaped the attention of U.S. scholars. ${ }^{2}$ The issue is of considerable current interest because the American Law Institute has embarked on the project of elaborating a Third Restatement of Conflict of Laws, and the current draft of this restatement addresses these provisions in a way that differs significantly from how the issue was addressed in the Second Restatement of Conflict of Laws. ${ }^{3}$

The difference between the two restatements' understandings of such provisions is based on very different views of what counts as a choice-of-law rule. The debate about geographic scope limitations thus implicates fundamental questions about the nature of a choice-of-law inquiry and of a choice-of-law rule. The Second Restatement treated geographic scope provisions as choice-of-law rules. The Third Restatement, by contrast, takes the position that geographic scope provisions are not choice-of-law rules; they are instead inextricable parts of a state's substantive law. ${ }^{4}$ The restatements' different understandings of these provisions are reflected in the restatements' definitional provisions. The differing definitions, in turn, produce very different outcomes under the restatements' operative provisions, even though the operative provisions are phrased in almost identical terms.

\footnotetext{
${ }^{1}$ I use the term "state" to refer both to states of the United States, such as California, and foreign nations, such as France. When I mean to refer only to the former, I use the term "U.S. state."

2 Two notable exceptions are Peter Hay, Comments on "Self-Limited Rules of Law" in Conflicts Methodology, 30 AM. J. ComP. L. SupP. 129 (1982), and Robert Allen Sedler, Functionally Restrictive Substantive Rules in American Conflicts Law, 50 S. CAL. L. REV. 27 (1976), both of whom acknowledge that these provisions have received far greater attention from foreign scholars.

${ }^{3}$ This Article focuses on statutory provisions specifying the extraterritorial applicability of a state's law insofar as such provisions render the law inapplicable to the case at hand-that is, insofar as they limit the extraterritorial reach of a statute. Different questions arise when a provision specifies a statute's territorial reach in a way that renders the statute applicable to the case at hand. See infra text accompanying note (hereinafter "TAN") 54.

${ }^{4}$ In the interest of brevity, I shall henceforth refer to the current draft of the Third Restatement as the Third Restatement.
} 
For example, both restatements establish a presumption that a contractual choice-of-law clause selects the law of the chosen state exclusive of that state's choiceof-law rules. In the Second Restatement, that means the clause is presumed to select the chosen state's substantive law exclusive of any geographic scope limitations. Thus, if the parties agreed in a franchise agreement their contractual relation would be governed by the law of New York, the court will apply a New York statute regulating franchises, even if a geographic scope provision specifies that the statute applies only to New York franchises and the contract concerns a franchise operating elsewhere. In the Third Restatement, by contrast, the parties are not presumed to have excluded geographic scope limitations because such provisions are not considered choice-oflaw rules. Under the Third Restatement, the franchise agreement's selection of New York law will presumptively select the chosen state's statutes subject to their geographic scope limitations. ${ }^{5}$

The restatements' differing understandings of geographic scope limitations also produce different results on the question of renvoi. A court engages in renvoi when its choice-of law rules instruct it to apply the law of another state and, instead of applying that state's substantive law, the court applies the other state's choice-of-law rules. Thus, if State A's choice-of-law rules instruct the courts to apply the law of State $\mathrm{B}$ to a tort claim, a court that engages in renvo $i$ will apply the choice-of-law rules of State B, rather than State B's substantive tort law. As a result, depending on State B's choice-of-law rules, the State A court might wind up applying the tort law of State C. Both restatements prohibit renvoi in most cases. ${ }^{6}$ In the Second Restatement, the prohibition of renvoi means that, when a state's choice-of-law rules select the law of another state as the applicable law, the court will apply that state's substantive law, disregarding its geographic scope limitations. For the Third Restatement, giving effect to another state's territorial scope limitation does not count as renvoi. Rather, the Third Restatement maintains that a court purporting to apply the law of a given state is required to give effect to the geographic scope limitations in that state's statutes. Indeed, according to the Third Restatement, a U.S. state would violate the Full Faith and Credit Clause of the U.S. Constitution if it applied a sister state's substantive law while disregarding its geographic scope limitation.

This Article defends the Second Restatement's understanding that geographic scope limitations are choice-of-law provisions. Although they are written as limits on the substantive scope of the statutes, they reflect the legislator's deference to the legislative authority of other states. Because they tell us that cases beyond the specified scope of the state are to be governed by the law of another state, they are, in purpose

5 See infra notes 184-186 and accompanying text.

6 See infra TAN 23 and 28.

7 See infra TAN 137. 
and function, choice-of-law rules. Thus, when the parties in a contract choose the law of a given state to govern their contractual relationship, the operative provisions of both restatements should be read to establish a presumption that they selected the law of the chosen state shorn of any geographic scope limitations. Moreover, a court that gives effect to another state's geographic scope limitation does engage in renvoi. If a state's choice-of-law rules select the law of another state as applicable, then, according to both restatements' provisions on renvoi, the court should ordinarily apply that state's substantive law disregarding any statutory geographic scope limitations. A U.S. state's application of a sister state's substantive law to cases beyond its specified geographic scope would not violate the Full Faith and Credit Clause.

The Third Restatement's contrary position is based on the idea that geographic scope limitations are indistinguishable from any other limitation on the reach of a statute. For example, a legislature might enact a substantive rule and specify that it applies to persons over 18 years of age, or that it applies to conduct in parks or other public lands. (I call these "internal" scope limitations.) If a statute specifies that it applies to persons over 18 years of age, a court that applies the statute to someone under 18 years of age commits an error. Similarly, according to the Third Restatement, if State A's franchise act applies only to franchises operating in State A, a court commits an error if it applies the substantive provisions of the Act to a franchise that does not operate in State A.

I argue here that geographic scope limitations differ from internal scope limitations in a fundamental way. An internal scope limitation reflects the legislature's view that the substantive rule it is enacting is appropriate for persons or spaces falling within the statute's designated scope but inappropriate for persons or spaces beyond its scope. An internal scope limitation leaves persons or spaces beyond the statute's scope to be governed by a different rule or principle of that state. A geographic scope limitation, by contrast, is best understood to reflect the legislature's desire to defer to another state's claim to regulate the matter at hand. When the legislature specifies that the statute applies to disputes having certain connections to the state, it is not conveying the view that disputes lacking such a connection are more appropriately governed by a different substantive rule. It is, rather, conveying its willingness to defer the regulation of such cases to another state. Because the purpose of such provisions is to allocate legislative competence as between the enacting state and other states, these provisions are properly regarded as choice-of-law provisions. Because such provisions reflect deference to other states, those other states do not disrespect the enacting legislature's wishes when they apply the substantive rule beyond its specified scope. If anything, they are giving more faith and credit to such laws than the enacting state has asked for. 
Most importantly, under a proper understanding of a geographic scope limitation, the enacting state does not have a substantive rule to govern cases beyond the statute's specified scope. The geographic scope limitation instead reflects the legislature's view that the case is more properly governed by the law of another state. If the courts of another state wish to be faithful to the enacting legislature's wishes, they would treat the provision as an invitation to apply the law of another state. But they are not required to do so, and, indeed, if their own choice-of-law rules prohibit renvoi, as both restatements do for most cases, they will not do so. If a contractual choice-of-law clause or the choice-of-law rules of the forum select the law of a state that has a statute addressing the relevant issue, the courts are free to apply the substantive provisions of that statute even if the case is beyond the statute's reach as specified by a geographic scope limitation.

Mine is primarily a conceptual argument about the nature of geographic scope limitations. It is not a normative argument about what a restatement should say about the interpretation of choice-of-law clauses or renvoi. Nevertheless, my discussion of geographic scope limitations will show that the presumption established in the Second Restatement regarding contractual choice-of-law clauses is the only reasonable approach to the issue. The proper treatment of renvoi is a more contentious topic, but my analysis suggests that the hostility towards renvoi reflected in both restatements is not entirely warranted.

Although I use the restatements' contrasting understanding of geographic scope limitations to frame my discussion, the issue is of more general-and more global-interest. For example, the European Union has adopted regulations to govern choice of law in contractual cases (the so-called Rome I regulations) and in noncontractual cases (Rome II). Both regulations expressly prohibit renvoi. ${ }^{8}$ Some European scholars have taken the position that this prohibition does not preclude application of geographic scope limitations.' My argument here supports the position that the Rome Regulations' exclusion of renvoi requires Member States to apply the law that such states would apply to the purely local case, disregarding any geographic scope limitations.

This Article's thesis also has relevance beyond geographic scope limitations found in statutes. Courts often read a geographic scope limitation into statutes that do not address their territorial scope. The U.S. Supreme Court, for example, applies

8 See Article 20, Regulation (EC) no. 593/2008 on the law applicable to contractual obligations (Rome I Regulation) ("The application of the law of any country specified by this Regulation means the application of the rules of law in force in that country other than its rules of private international law, unless provided otherwise in this Regulation"); Article 24, Regulation (EC) no. 864/2007 on the law applicable to non-contractual obligations (Rome II Regulation) (same).

9 See infra notes 221-228. 
a presumption against extraterritoriality to limit the reach of federal statutes that do not expressly address the question of territorial scope. ${ }^{10}$ Some U.S. states apply a similar presumption in interpreting their own statutes. ${ }^{11}$ Going further, some scholars, including the reporter of the Third Restatement, maintain that the first step of any choice-of-law inquiry is to determine the geographic scope of the contending laws. ${ }^{12}$ Going further still, according to one school of thought long dominant in the United States, the point of all choice-of-law rules is to delimit the territorial scope of forum law. ${ }^{13}$ This Article focuses on geographic scope limitations found in statutes because such statutory provisions pose the issues under discussion most starkly. What I say about geographic scope limitations in statutes, however, applies a fortiori to geographic scope limitations read into a state's law through judicial interpretation.

Part I of this Article explains in greater detail how the Second and Third Restatements address geographic scope limitations. Part II defines the concept of a geographic scope limitation and distinguishes it from an internal scope limitation. Part III addresses one of the reasons given by the Third Restatement for rejecting a distinction between geographic scope limitations and internal scope limitations: that the distinction is too difficult to administer. Part III considers a variety of scope limitations that might be difficult to classify as either a geographic scope limitation or an internal scope limitation and concludes that the difficulty is far from insuperable.

Part IV considers possible understandings of geographic scope limitations as something other than a choice-of-law rule. In particular, I examine and reject the possibility that, when a state's legislature enacts a statute that includes a geographic scope limitation, cases beyond the statute's reach because of a geographic scope limitation are governed by another substantive rule of the same state. I argue that this is an implausible understanding of what a legislature means when it enacts a geographic scope limitation and that, if a geographic scope limitation in a statute enacted by a U.S. state were so interpreted, it would be unconstitutional. Part V considers and rejects the claim that a U.S. state's application of a sister state's substantive law to cases beyond the law's specified geographic scope violates the Full Faith and Credit Clause. Part VI explains why my conclusion that courts can properly apply the substantive

\footnotetext{
10 See, e.g., Morrison v. Nat'l Austl. Bank Ltd, 561 U.S. 247 (2010).

11 See, e.g., cases cited infra note 189.

12 See Kermit Roosevelt III, Resolving Renvoi: The Bewitchment of Our Intelligence by Means of Language, 80 Notre Dame L. Rev. 1821 (2005). Professor Roosevelt is the reporter for the Third Restatement of Conflict of Laws.

13 I discuss this view in Carlos M. Vázquez, Choice of Law as Extraterritoriality, available at https://papers.ssrn.com/sol3/papers.cfm?abstract $\mathrm{id}=3525111$, published in the volume RESOLVING CONFLICTS IN THE LAW: ESSAYS IN HONOUR OF LEA BRILMAYER (Chiara Giorgetti \& Natalie Klein eds., Boston: Brill Nijhoff 2019) under the title Choice of Law as Geographic Scope Limitation.
} 
laws of another state to cases beyond their specified scope is consistent with the obligation of courts to adjudicate cases according to law.

Finally, Part VII considers the implications of my analysis for the two issues addressed in the restatements for which the characterization of geographic scope limitations as choice-of-law rules (or not) plays a central role. First, I consider the significance of my analysis for the treatment of contractual choice-of-law clauses. Lastly, I consider what my analysis of geographic scope limitations suggests about the proper approach to renvoi.

I. Geographic Scope Limitations in the Second And Third RESTATEMENTS

The restatements' different understandings of geographic scope provisions are made clear in their definitional sections. These definitions interact with the restatements' operative provisions to produce different results in certain contexts. The most relevant of the operative provisions are those concerning renvoi and the interpretation of contractual choice-of-law clauses. This Part discusses the treatment of geographic scope limitations in the definitional sections of the two restatements and explains how the restatements' different definitions produce different results with respect to the two operational provisions just mentioned.

Assume that the parties to a franchise agreement stipulate in the contract that their relationship shall be governed by the law of the State A. Assume further that a dispute arises within the scope of the choice-of-law clause, and that State A has a statute addressing the issue involved in the dispute. Assume further, however, that the statute stipulates that it applies to franchises operating in State A, and this franchise does not operate in State A. Should the judge resolve the dispute by applying the substantive provisions of the statute as if the franchise did operate in State A? Or should the court not apply the statute because, by its terms, it does not extend to this franchise? The answer to this question, under both the Second and Third Restatements, turns on whether the provision limiting the scope of State A's statute to franchises operating in State A is a choice-of-law rule. The two restatements answer that question differently.

Under the Second Restatement, a geographic scope limitation is a choice-oflaw rule, and the court in our hypothetical case would apply the substantive provisions of the Franchise Act, disregarding its geographic scope limitation. The Second Restatement provides in section 187(3) that, when the parties to a contract agree that the contract will be governed by the law of a particular state, "in the absence of a contrary indication of intention, the reference is to the local law of the state of the 
chosen law."" The Second Restatement defines "local law" as "the body of standards, principles and rules, exclusive of its rules of Conflict of Laws, which the courts of that state apply in the decision of controversies brought before them." ${ }^{15}$ The Second Restatement distinguishes a state's "local law" from its "whole law," which it defines as its "local law, together with its rules of Conflict of Laws." 16 The Second Restatement defines "Conflict of Laws" broadly as "that part of the law of each state which determines what effect is given to the fact that the case may have significant relationship to more than one state."17 A legal provision that specifies that State A's Franchise Act applies to franchises operating in State A presupposes that some franchises may operate in other states and specifies the legal effect to be given to that fact. Under the Second Restatement, therefore, such limitations are choice-of-law rules ${ }^{18}$ and are presumptively to be disregarded when a contractual choice-of-law clause selects State A law as the applicable law. ${ }^{19}$

The Third Restatement includes a provision very similar to section 187(3) of the Second Restatement. Section 8.03 addresses the "Interpretation of Choice-of-Law Clauses," and provides, in subsection c, that a choice-of-law clause's "reference to the 'law' or 'laws' of a particular State is presumed to select the internal law, rather than the whole law, of that State." 20 Another provision defines "internal law" in terms very similar to the Second Restatement's definition of "local law." Section 1.03 defines "internal law" of a state as "a state's law exclusive of its rules of choice of law." But a comment makes clear that the term "internal law" includes "both specifications of the persons who can assert rights under the law and specifications of the geographic scope

\footnotetext{
${ }^{14}$ Second Restatement $\ 187(3)$.

${ }^{15}$ Second Restatement $\ 4(1)$ (emphasis added).

${ }^{16} I d$. at $\int 4(2)$.

${ }^{17} I d . \$ 2$.

${ }^{18}$ The Second Restatement defines "local law" as a state's law exclusive of its rules of "Conflict of Laws" (emphasis added). Nevertheless, if geographic scope limitations are Conflict of Laws rules within the meaning of Second Restatement $\ 4(2)$, as the discussion in the text shows, it is because they are choice-of-law rules. The field of Conflict of Laws consists of three branches: judicial jurisdiction, choice of law, and enforcement of foreign judgments. See Second Restatement, $\mathbb{S}$ 1(2)(a). A geographic scope limitation is clearly not a rule of judicial jurisdiction or enforcement of foreign judgments. Thus, if it is a rule of Conflict of Laws, that is because it is a rule of choice of law.

19 This conclusion is confirmed by the Second Restatement's provision on renvoi, discussed below, which shows clearly that a state's local law is the law the state would apply to a case that is "purely local to it." A number of courts applying the Second Restatement have either overlooked section 187(3) or have mistakenly interpreted "local law" in the way the Third Restatement defines "internal law." I discuss these cases in Part VII. See generally Hannah L. Buxbaum, Determining the Territorial Scope of State Law in Interstate and International Conflicts: Comments on the Draft Restatement (Third) and on the Role of Party Autonomy, 27 Duke J. CoMP. \& INT'L L. 381, 397-401 (2017) (discussing cases).

20 Third Restatement, Preliminary Draft No. 5 (Oct. 23, 2019), $\ 8.03$.
} 
of the law." 21 The comment acknowledges that this definition may differ from the Second Restatement's definition of "local law." 22 The comment necessarily reflects the understanding that a geographic scope limitation is not a choice-of-law rule. Because a geographic scope limitation is not a choice-of-law rule and is thus a part of a state's "internal law," section 8.03(2)(c)'s presumption that a choice-of-law clause selects a state's "internal law" does not establish a presumption that courts are to disregard the state's geographic scope limitation.

The restatements' different views about whether a geographic scope limitation is a choice-of-law rule also has direct relevance to the provisions of those restatements concerning renvoi. Both the restatements reject renvoi in most cases. Section 8 of the Second Restatement provides that, "[w] hen directed by its own choice-of-law rule to apply 'the law' of another state, the forum applies the local law of the other state [except in two specified circumstances]." 23 Comment $d$ to this section explains that "the result reached will be that which would have been reached by a court of the other state if the case had involved facts purely local to it." That a state's local law is the law that it applies to cases "purely local to it" is confirmed by Illustration 1 :

A, a national of state $\mathrm{X}$ who is domiciled in state $\mathrm{Y}$, dies intestate leaving chattels in state $\mathrm{X}$. A proceeding is brought in state $\mathrm{X}$ to determine how the chattels should be distributed. Under the X choice-of-law rule, the distribution of moveables upon intestacy is determined by the law of the deceased's domicile at the time of death. ... If the X court decides that the reference is to Y local law, it will decide the case in the same way as a $Y$ court would have decided if $A$ had been a $Y$ national and if all other relevant contacts had been located in $Y^{24}$

This comment and Illustration confirm that a state's "local law" is the law that the state applies to dispute in which all the parties are from the state and all other relevant

21 Third Restatement, Tentative Draft No. 1 (April 21, 2020), $\$ 1.03$ comment a.

${ }^{22} I d$.

${ }^{23}$ Second Restatement $\int 8(1)$.

${ }^{24}$ Second Restatement, $\int 8$, comment d, Illustration 1 (emphasis added). Although the Third Restatement acknowledges that its definition of internal law may differ from the Second Restatement's definition of "local law," see supra text accompanying note 22, its reporter is not quite ready to concede that point. He has argued that a geographic scope limitation is part of the law that the state applies to the purely local case, but the limitation is "invisible" in such cases because the facts do not call for its application. See Letter from Kermit Roosevelt to Carlos M. Vázquez (June 28, 2016) (on file with author). This argument proves too much. The Third Restatement recognizes that choice-of-law rules are not part of a state's local law (or its internal law), yet such rules could equally be regarded as parts of the state's law that are "invisible" in purely local cases. The point of the Second Restatement's definition of local law is to exclude such invisible parts of a state's law. 
facts occurred in the state. ${ }^{25}$ This understanding of the terms "local law" and "internal law" has a long and distinguished pedigree. ${ }^{26}$ In light of this understanding, if State B follows the Second Restatement and that Restatement's choice-of-law provisions relating to torts call for the application of the law of State A, State B's courts would apply the tort law that State A courts would apply to the "purely local" case. If State A has a statute that by its terms applies only to cases in which the injury occurred in State A, State B's courts would disregard that limitation and apply the substantive provisions of the statute even if the injury occurred in State C. ${ }^{27}$

25 That the Second Restatement understands "local law" as the law that applies in purely local cases is further confirmed by other parts of the Second Restatement, albeit more subtly. For example, section 145 comment $i$, provides that "when certain contacts involving a tort are located in two or more states with identical local law rules on the issue in question, the case will be treated for choiceof-law purposes as if these contacts were grouped in a single state." Similar comments appear throughout the Second Restatement. See Section 186, comment c (contracts); section 221, comment $\mathrm{f}$ (restitution); section 222, comment $\mathrm{f}$ (real property); section 244, comment $\mathrm{n}$ (chattels); section 283, comment $\mathrm{n}$ (marriage); section 287, comment $\mathrm{i}$ (legitimacy); section 291, comment $\mathrm{h}$ (agency); section 302, comment k (corporate liability). Under an understanding of "local law" as the law that applies in purely local cases (i.e., disregarding geographic scope limitations) this comment operates straightforwardly and sensibly. But the approach contemplated in these comments does not make any sense if "local law" were understood as a state's substantive law subject to its geographic scope limitations. It is difficult to understand why one would group contacts in a single state for purposes of determining which state has the most significant relationship to the dispute when the states had identical substantive laws and identical geographic scope limitations, but not when they have different scope limitations.

${ }^{26}$ See, e.g., Joseph M. Cormack, Renvoi, Characterization, Localization and Preliminary Question in the Conflict of Laws: A Study of Problems Involved in Determining Whether or Not the Forum Should Follow Its Own Choice of a Conflict-of-Laws Principle 14 S. CAL. L. REV. 221, 249 (1941) ("The domestic, or internal, law is that which a court of the foreign jurisdiction applies when all the facts are local to, that is, occurred within, that jurisdiction."); Erwin Griswold, Renvoi Revisited, 51 HARV. L. REV. 1165, 1166 (1938) ("Now the question obviously arises: when the English conflicts rule directs the court to 'the law of' France, is the reference (a) simply to the 'internal law' of France, that is, the law which a French court would apply to a situation all of whose elements were French, or is it (b) to what might be called the 'whole law' of France, including not only the French internal law but also the French rules of conflict of laws?"); Elliott E. Cheatham, Internal Law Distinctions in the Conflict of Laws, 21 CoRnell L. Q. 570, 571 (1936) ("The 'internal law' of a state is the law applied to internal or local cases, cases with all their elements in the state."); Frederick Pollock, The Renvoi' in New York, 36 L. Q. REV. 91, 91-92 (1920) (French "internal" law as applied by a New York court to a New York testator means "the French rules as if the testator had been a Frenchman."); Albert V. DiCEy \& John H. C. Morris, CONFlict OF LAWs 53 (9th ed. 1973)) ("The term, llaw of a country', e,g, the law of England or the law of Italy is, as already explained, ambiguous. It means in its narrower and most usual sense the domestic law of any country, i.e., the law applied by its courts in cases which contain no foreign element. It means in its wider sense all the rules, including the rules of the conflict of laws, which the courts of a country apply."); See also infra note 44.

${ }^{27}$ Relying on a comment to section 6(1), the reporter of the Third Restatement has argued that the Second Restatement is ambiguous about whether geographic scope limitations are choice-of-law 
The current draft of the Third Restatement also purports to reject renvoi for most cases. Section 5.05 provides that, "[w] hen the forum's choice-of-law rules direct it to apply the law of some state, the forum applies the internal law of that state, except as stated in subsection (2)." 28 However, because "internal law" is understood to include provisions limiting the geographic scope of a state's law, this provision does not contemplate the application of the substantive provisions of a statute to cases beyond the statute's specified geographic scope. Because such scope limitations are not regarded as choice-of-law rules, giving effect to such provisions does not count as renvoi. The Third Restatement makes clear that "a foreign statute that specifies its scope must be applied as written and cannot, through choice-of-law analysis, be

rules. See Letter from Kermit Roosevelt to Carlos M. Vázquez (July 5, 2016) (on file with author). See also Buxbaum, supra note 19, at 397 (citing this comment and noting the "ambiguity" of the Second Restatement on the meaning of "local law"). But the comment is entirely consistent with my analysis in the text. The black letter of section 6(1) of the Second Restatement provides that "[a] court, subject to constitutional restrictions, will follow a statutory directive of its own state on choice of law." Comment b to this subsection provides:

Intended range of application of statute. A court will rarely find that a question of choice of law is explicitly covered by statute. That is to say, a court will rarely be directed by statute to apply the local law of one state, rather than the local law of another state, in the decision of a particular issue. On the other hand, the court will constantly be faced with the question whether the issue before it falls within the intended range of application of a particular statute. The court should give a local statute the range of application intended by the legislature when these intentions can be ascertained and can constitutionally be given effect. . . . [] f the legislature intended that the statute be applied only to acts taking place within the state, the statute should not be given a wider range of application. ... Provided that it is constitutional to do so, the court will apply a local statute in the manner intended by the legislature even when the local law of another state would be applicable under usual choice-of-law principles.

The comment does suggest that a provision specifying a statute's "range of application" is not an "explicit" choice-of-law rule. This is true- such a provision is typically framed as a specification of the statute's geographic scope rather than as a choice-of-law rule. But it is nevertheless an implicit choice-of-law rule. That is the unambiguous import of section 8 in comment $\mathrm{d}$, and especially Illustration 1, and it is my argument here. If anything, comment b to section 6(1) supports my conclusion. After all, the comment instructs courts to give effect to geographic scope limitations enacted by their own legislatures, and it does so in explaining the import of the black letter of section 6(1), which provides that a court "will follow a statutory directive of its own state on choice of law." (emphasis added).

${ }^{28}$ Third Restatement, Council Draft No.1, $\ 5.05(1)$ (Nov. 11, 2016). Subsection 2 provides that, "[w]hen the objective of the particular choice-of-law rule is that the forum reach the same result on the facts as would the courts of another state, the forum applies the choice-of-law rules of the other state, subject to considerations of practicability and feasibility." 
extended to a set of facts that falls outside its specified scope." 29 Indeed, the Third Restatement takes the position that a U.S. state violates the Full Faith and Credit Clause if it fails to give effect to a geographic scope limitation in a sister state's law. ${ }^{30}$

This Article defends the Second Restatement's understanding that geographic scope limitations are choice-of-law rules. Thus, as "local law" is defined in the Second Restatement and as "internal law" is defined in the black letter of the Third Restatement, both restatements should be understood to establish a presumption that contractual choice-of-law provisions selecting a state's law select the law that the state would apply to "purely local" cases. Additionally, under their black letter definitions of "local law" and "internal law," respectively, both restatements should be understood to provide that, when the forum's choice-of-law rules select another state's law, the court should apply the law the state would apply to "purely local" cases, and thus disregard a geographic scope limitation, except in the types of cases in which renvoi is permitted. At the same time, as discussed in Part VII, my analysis in this Article supports a broader availability of renvoi, at least in cases involving statutes with geographic scope limitations.

\section{GEOGRAPHIC VS. INTERNAL SCOPE LIMITATIONS}

The type of provision on which this Article focuses-which I have called a geographic scope limitation-has gone by a variety of names in the Conflict of Laws literature. In his 1943 treatise, PrinCIPLES of Private InTERnational LAw, Arthur Nussbaum referred to such provisions as "spatially-conditioned internal rules." 31 As examples, he cites "an exemption statute [that] reserve[s] its benefits to local residents, or an insurance statute [that] confine[s] its regulations to insurance contracts made within the state." 32 He notes that "the realm of 'spatially conditioned' internal rules is wide and unexplored," and that examination of such rules "should form an integral part in any complete discussion of Private International Law." "33 Nevertheless, he discusses such rules only briefly in his treatise. ${ }^{34}$ His analysis supports the Third Restatement's view that such spatial conditions are not choice-of-law rules, but his analysis is brief and conclusory.

\footnotetext{
${ }^{29} I d$. comment k.

${ }^{30} I d$. $\int 5.02$ comment b to subsection (1).

31 Arthur Nussbaum, Principles of Private International LaW 71 (1943).

32 Id. at 72,73 .

33 Id. at 72, 73. "Private international law" is the term used, primarily in civil law countries, to describe the field of law that is known in common law countries as "Conflict of Laws." See id. at 3. In this Article, I use the terms synonymously.

34 He stated that "the realm of 'spatially conditioned' internal rules . . . cannot be further probed within the scope of the present study" beyond the five pages he devotes to them. Id. at 72.
} 
Italian scholar Rodolfo de Nova calls these provisions "self-limiting rules" and statutes containing these provisions "self-limited laws.", Australian scholar David St. Leger Kelly calls them "localising rules." "36 Anglo-German scholar Kurt Lipstein has called them "inherent limitations in statutes" and has noted that others have called them "spatially conditioned internal rules," "legislatively localised rules," "laws containing localising limitations," "functionally restricting rules," and "special substantive rules for multi-State problems. ${ }^{37}$

British scholar John H.C. Morris, in The Choice of Law Clause in Statutes, divides statutes into three categories: (1) those that do not address choice-of-law; (b) those with a "general choice of law clause," meaning a clause that specifies the state whose shall govern for a particular class of cases; and (c) statutes containing "a particular choice of law clause purporting to delimit the scope of a rule of domestic law." gives as an example of the second category a statute providing that the validity of a will of movables shall be governed by the law of the place of execution. ${ }^{39}$ He equates the third category with what Nussbaum denominates a "spatially-conditioned internal rule," but, as the title of Morris' article indicates, he disagreed with Nussbaum's conclusion that these are not choice-of-law rules. He does, however, recommend that legislatures employ the second rather than the third type of clause: "Confusion is bound to result unless a clear distinction is maintained between domestic rules and conflicts rules, and a statute with a particular choice of law [provision] is a bastard hybrid." 40

Morris's successor as co-author of the Dicey \& Morris treatise on the Conflict of Laws, Lord Collins, notes that "conflict rules are of two kinds, particular or unilateral and general or multilateral. "41 As an example of a unilateral conflict of laws rule, the treatise cites the Marriage (Scotland) Act, which provides that "[n]o person domiciled in Scotland may marry before he attains the age of 16." the limitation of the provision to persons domiciled in Scotland is a "conflict of laws"

\footnotetext{
${ }^{35}$ See, among his many works addressing the issue, Rodolfo De Nova, Self-Limiting Rules and Party Autonomy, 5 ADEL. L. REV. 1 (1973); Rodolfo De Nova, Conflits de loi et norms fixant leur propre domain d'application, 1 MÉLANGES JACQUES MAURY 377 (1960).

36 David St. Leger Kelly, Localising Rules in the Conflict of Laws (1974). See also D. St. L. Kelly, Localising Rules and Differing Approaches to the Choice of Law Process, 18 INT'L \& COMP. L. Q. 249 (1969).

${ }^{37} \mathrm{~K}$. Lipstein, Inberent Limitations in Statutes and the Conflict of Laws, 26 INT'L \& COMP. L.Q. 884, 885 (1977).

38 J.H.C. Morris, The Choice of Law Clause in Statutes, 62 L.Q. REV. 170 (1946).

${ }^{39} \mathrm{Id}$. at 173. Such statutes, he says, 'are rare." Id.

${ }^{40} \mathrm{Id}$. at 172 .

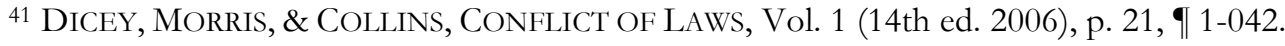

${ }^{42}$ Id., ๆ $1-044$.
} 
provision and thus that a court that rejects renvoi would disregard it. ${ }^{43}$ All of this is consistent with the Second Restatement's understanding of "internal law" and of "renvoi." 44 The distinction is also consistent with Morris's analysis and with that of other scholars who regard these provisions as unilateral choice-of-law rules. ${ }^{45}$

But, confusingly, Collins goes on to distinguish statutes that include unilateral conflicts rules from "self-limiting statutes." The latter include statutes that "provide that some of its provisions apply only to British citizens, or to British ships, or to the capital city, or on Sundays, or during the close season for various classes of game birds, or to certain kinds of employees." "46 Such "self-limiting" provisions, according to the treatise, "are clearly not rules of the conflict of laws whether multilateral or unilateral." ${ }^{47}$ Insofar as the treatise is referring to provisions limiting the statute's applicability to the capital city or to Sundays or to the close season or to certain types of employees, the distinction between such limitations and unilateral conflict of laws rule corresponds to my distinction between geographic scope limitations and internal scope limitations. (Even though the treatise calls the latter "self-limiting statutes," they are not what De Nova means by this term.) Insofar as a provision limits the statute's applicability to British citizens or British ships, however, Collins' distinction between self-limiting statutes and unilateral conflict of laws rules is elusive. In my terminology, these are examples of geographic scope provisions. The treatise does not explain, and it is difficult to fathom, why the limitation of the Marriage (Scotland) Act to "persons domiciled in Scotland" is a unilateral conflicts rule while provisions that limit a law's

${ }^{43} \mathrm{Id}$. The treatise notes that a statute containing a unilateral conflict rule "can be dissected into (a) a rule of domestic law, and (b) a conflict rule indicating when the rule of domestic law is to apply." Id. In the case of the Marriage (Scotland) Act, the conflict rule is the limitation of the statute's scope to persons domiciled in Scotland. The rule of domestic law (the "internal law," if one defines that term as the state's laws exclusive of its conflict of laws rules) is that persons may not marry before they have reached the age of 16. My analysis calls for a similar dissection of statutes containing geographic scope provisions.

44 Also consistent with the Second Restatement's understanding of the term is the treatise's distinction between a narrower and a broader view of the term "law." In its discussion of renvoi, the treatise explains that: "The term 'law of a country,' e.g., the law of England or the law of Italy is ambiguous. It means in its narrower and most usual sense the domestic law of any country, i.e., the law applied by its courts in cases which contain no foreign element. It means in its wider sense all the rules, including the rules of the conflict of laws, which the courts of a country apply." Id. at 73, 9-002. (This same point appears in the 15th edition at 77, 9 4-002.) If the "narrower" sense of the term "law" corresponds to the concept of "local law," the treatise seems to be embracing here the Second Restatement's understanding of the latter term.

45 See, e.g., Symeon C. Symeonides, Choice of Law: The OXford Commentaries on AMERICAN LAW 494 (2016) ("Despite their location in substantive statutes (and despite their variations in content and wording), all of these localizing provisions qualify as choice-of-law rules, albeit of the unilateral type.”). This is also the import of the authorities cited supra note 26.

46 DICEY, supra note 41, p. 23, ๆ 1-049.

${ }^{47} I d$. 
reach to British citizens or ships are not conflicts rules at all. Collins himself recognizes the elusiveness of this distinction, acknowledging that "it is not always easy to distinguish between unilateral conflict rules and self-limiting provisions; nor has any writer succeeded in formulating a satisfactory test for distinguishing between them." ${ }^{48}$

In Part III, I consider some borderline cases and take up the challenge of formulating a satisfactory test for distinguishing between geographic scope limitations and internal scope limitations. In the remainder of this Part, I set forth my general test for distinguishing the two. I use the term "internal scope limitation" instead of Collins' term "self-limiting provisions" because, as we have seen, De Nova and others use the term "self-limiting statute" to refer to statutes that contain what I call geographic scope limitations. Moreover, some types of provisions that Collins regards as "self-limiting provisions" are, under my definition, geographic scope limitations while others are internal scope limitations. I use the term "geographic scope limitation" instead of "spatially-conditioned internal rule" because that is the term that the Third Restatement has used to describe this concept. ${ }^{49}$ Notwithstanding the word "geographic," however, the reader should keep in mind that the term is not limited to provisions that specify the scope of a law by reference to the territory on which conduct occurred; it also refers to provisions that specify a statute's scope according to the domicile, residency, or nationality of persons.

Internal Scope Limitations. Many statutes include limitations on the scope of their internal applicability. A statute that prohibits vehicles in the park applies only in parks. A securities statute may set forth certain regulations for securities sold in the stock market. These regulations do not apply to securities not sold in stock markets. I call these "internal" scope limitations because they limit the applicability of the statute even when all of the relevant facts occurred within the state and all parties are principally affiliated with the enacting state. When a state's legislature enacts a substantive rule but imposes an internal scope limitation, purely local cases falling outside of the statute's scope are governed by another law of that state. The provision reflects the legislator's judgment that cases outside the statute's designated scope should be governed by a different substantive rule. That other rule may be permissive-for example, vehicles are not prohibited and are thus permitted outside parks. Such a law reflects the legislator's judgment that vehicles should be permitted outside of parks.

Geographic Scope Limitations. As I define the term here, a geographic scope limitation is one that specifies the applicability of the substantive rule by reference to the existence of some connection with the enacting state, such as a provision specifying

48 Id., ๆ 1-051.

49 See, e.g., Third Restatement, supra note 21 , comment a to $\$ 1.03$. 
that the statute applies to conduct that occurs within the state or to persons domiciled in the state. The Third Restatement insists that these provisions are not choice-of-law rules. Rather, for choice-of-law purposes, they are indistinguishable from what I am calling an internal scope limitation. Both are integral parts of the state's substantive law. These conclusions follow from the Third Restatement's understanding of the nature of the choice-of-law process, which draws from the scholarship of Brainerd Currie, the father of governmental interest analysis.

Currie argued that the first step in resolving a choice-of-law problem is to determine the geographic scope of the laws of the states having connections to the case. This question, in turn, is just like any other issue of statutory interpretation. In the purely domestic case, the court must interpret the statute to determine whether it applies to certain marginal domestic circumstances (for example, does a statute prohibiting vehicles in the park apply to bicycles?). Determining whether the statute applies to certain disputes having foreign elements, according to Currie, is basically the same problem, and it should be approached in the same way. ${ }^{50}$ Currie argued that the courts should ascertain a statute's geographic scope by applying ordinary rules of statutory interpretation. The court should "try] to decide [the question of geographic scope] as it believes [the legislature] would have decided had it foreseen the problem." 51 Thus, he argued, the courts should seek to determine the purpose of the statute (or common-law rule) and should conclude that the rule extends to the case if its purposes would be advanced by applying it to the case. In a case that has connections to two states, a court should begin by interpreting the laws of both states with respect to their geographic scope. This analysis may reveal that only one of the states' laws extends to the case. If so, there is no true conflict. (Currie called these "false conflict" cases.) ${ }^{52}$ The court should apply the only law that extends to the case. A true conflict exists only if both states' laws extend to the case. In such a case, the court must reach the second step of resolving the conflict.

The Third Restatement embraces this two-step approach to choice of law. As the reporter of the Third Restatement has written, "[Currie's] fundamental insightthat choice-of-law analysis can largely be assimilated to the process of determining the scope of state-created rights in purely domestic cases-is a tremendous conceptual

50 See Brainerd Currie, Comments on Babcock v. Jackson, A Recent Development in Conflicts of Laws, 63 Colum. L. Rev. 1233, 1242 (1963).

${ }^{51}$ Brainerd Currie, The Verdict of the Quiescent Years: Mr. Hill and the Conflict of Laws, 28 U. CHI L. REV. 258, 277 (1961).

52 See Brainerd Currie, The Constitution and the Choice of Law: Governmental Interests and the Judicial Function, 26 U. CHI. L. REV. 9, 10 (1958). 
advance." 53 The comments to the Third Restatement explain the "nature" of choice of law in terms similar to Currie's:

Resolving a choice of law question requires two analytically distinct steps. First, it must be decided which states' laws are relevant, in that they might be used as a rule of decision. This is typically a matter of discerning the scope of the various states' internal laws: deciding to which people, in which places, under which circumstances, they extend rights or obligations. Second, if state internal laws conflict, it must be decided which law shall be given priority. ${ }^{54}$

The Third Restatement agrees with Currie's understanding of the first step of this analysis as being a matter of determining the geographic scope of the substantive law. Like Currie, the Third Restatement understands this to be a matter of interpreting the substantive law with respect to its geographic scope. The question is no different than interpreting the law with respect to its applicability in a purely local case. A choice-oflaw question arises only at the second step, in determining which law will be applied when more than one law reaches the case. A state's choice-of-law rules are those that a court applies at this second step (which the Third Restatement denominates "rules of priority"). Because the question at the first step is one of interpreting the substantive law, the interpretations reached by the courts of the enacting state are authoritative.

Currie and the Third Restatement are here describing the nature of the choiceof-law process even when the contending laws do not contain a statutory provision specifying the law's geographic scope. When the law contains a geographic scope provision, the court's role is simpler. The geographic scope limitation tells us whether there law extends to the case, so there is no need for interpretation. According to the Third Restatement, if the scope limitation tells us that the substantive law does not extend to the case at hand, the court must simply apply the geographic scope provision as written. For present purposes, the important point is that, according to the Third Restatement, geographic scope is an aspect of a state's substantive law, no different from limits applicable in the purely domestic situation. Just as a court of another state is bound by the statute's limits in the domestic context (e.g., what counts as a "vehicle"

${ }^{53}$ Roosevelt, supra note 12, at 1856. See also Letter from Kermit Roosevelt to Carlos M. Vázquez (June 28, 2016) (on file with author) ("[Currie's] central insight was that determining scope in conflict of laws cases (his first step) was no different from determining scope in domestic cases. That is, it was just the ordinary process of statutory construction. Currie said this repeatedly.")

${ }^{54}$ Restatement (Third) of Conflicts of Laws, Tentative Draft No. 2, \$ 5.01 comment b (Apr. 21, 2020). See also Restatement (Third) of Conflicts of Laws, Preliminary Draft No.1, \$5.01 comment b (October 1, 2015) (same text preceded by the heading "Nature of choice of law"). 
that may not be used in a park), it is bound by the limits incorporated into the statute regarding its geographic scope. ${ }^{55}$

But the Third Restatement's analysis misses a fundamental difference between geographic scope limitations and internal scope limitations. As noted, when the legislature attaches an internal scope limitation to a statute, it has determined that the substantive rule is appropriate for the included cases but inappropriate for the excluded cases. With respect to the purely internal case having no foreign elements, the legislature has plenary authority to enact a rule to govern the case and yet it has concluded, for whatever reason, that only certain things (vehicles) should be banned from parks, and that such machines should be banned from parks but not other spaces. The excluded cases are subject to a different substantive rule of that state. The state has a rule for parks (vehicles are prohibited), but it also has a rule for spaces other than parks (vehicles are permitted, unless banned by another law of that state).

A geographic scope limitation is different. If a state enacts a substantive rule and stipulates that the rule is applicable to conduct performed within the state, or to domiciliaries of the state, it is not necessarily saying that the rule is inappropriate for conduct that takes place outside the state, or for persons who are not domiciled in the state. Indeed, presumably it enacted the rule because, in its view, it is the best rule to govern the type of issue it addresses. It nevertheless limits the application of the rule to conduct or persons that have the specified connection to the state in order to accommodate the legislative authority and interests of other states. ${ }^{56}$

The requirement of some sort of link between the dispute and the enacting state is, indeed, a requirement of international law. In order to have jurisdiction to impose its law on a given matter, a state must have certain types of ties to the matter. For example, a state has jurisdiction to prescribe rules for conduct that occurs within its territory, or for conduct that has certain effects within its territory. ${ }^{57} \mathrm{~A}$ state also has jurisdiction to prescribe rules applicable to its own nationals, whether or not the conduct took place within, or had effects in, its territory. ${ }^{58}$ A state also has jurisdiction under certain circumstances over conduct outside its territory that harms its nationals, ${ }^{59}$ or is directed against the security or against other fundamental interests of

\footnotetext{
${ }^{55}$ As discussed in Part IV, Currie himself does not draw the same conclusion. Rather, he appears to regard implicit geographic scope limitations as choice-of-law rules.

${ }^{56}$ For a related but distinct argument that determining a law's geographic scope is very different from determining its internal (or "domestic") scope, see Lea Brilmayer, Interest Analysis and the Myth of Legislative Intent, 78 MiCH. L. REV. 392, 417-21 (1980).

${ }^{57}$ Restatement (Fourth) of Foreign Relations Law $\$ 402(1)$ (a), (b) (2018).

${ }^{58} I d . \$ 402(\mathrm{c})$.

${ }^{59}$ Id. $\$ 402(\mathrm{~d})$.
} 
the state. ${ }^{60}$ With respect to a limited set of human rights norms, states have "universal jurisdiction," allowing them to prescribe rules in the absence of any connection to the parties or conduct. ${ }^{61}$ But, outside of that small set of cases, a connection between the state and the regulated party or conduct is required by international law.

In addition, the U.S. Constitution limits the legislative authority of U.S. states with respect to cases having foreign elements. The principal limits are imposed by the Due Process Clause of the Fourteenth Amendment and the Full Faith and Credit Clause, which permit a state to make its law applicable to cases having foreign elements if the state has "a significant contact or significant aggregation of contacts, creating state interests, such that choice of its law is neither arbitrary nor fundamentally unfair." ${ }^{\prime 2}$ The Due Process Clause of the Fifth Amendment may impose similar limits on Congress's power to make federal law applicable to cases lacking substantial connections to the United States. ${ }^{63}$ A geographic scope limitation will sometimes serve as the jurisdictional hook on which the state bases its legislative authority under international law or the Constitution.

Even within the limits imposed by international law and the Constitution, a state may decide to limit the scope of a given law to cases having certain links to the state for reasons of interstate or international comity. The legislature may have chosen the jurisdictional hook in order to coordinate application of laws on a particular issue at the interstate or international level with other states having a different substantive rule on the topic, perhaps because other states have used the same jurisdictional hook to specify the scope of their laws on the topic. If the legislature has chosen a different jurisdictional hook than other states have chosen, or if other states have not yet selected a jurisdictional hook for their laws on the topic, the legislature may have chosen its jurisdictional hook in order to signal to other states that may have a different substantive law on the issue that it would welcome their application of their law on the topic on the basis of the same sort of jurisdictional hook.

A legislature's selection of a geographic scope limitation for a given statute on the basis of one or more of the foregoing grounds is best regarded as a choice-of-law

\footnotetext{
${ }^{60} I d . \S 402(\mathrm{e})$

${ }^{61} \mathrm{Id}$. $\ 402(\mathrm{f})$

62 Allstate Ins. Co. v. Hague, 449 U.S. 302, 313 (1981) (plurality opinion). See also id. at 332 (Powell, J., dissenting) (noting that the Due Process Clause invalidates a state's application of its own law "when there are no significant contacts between the state and the litigation"). For a discussion of other constitutional provisions imposing limits on a state's authority to make its law applicable to cases having out-of-state elements, see BRILMAYER, GOLDSMITH, O'CONNOR O'HARA \& VÁZQUEZ, CONFLICT OF LAWS: CASES AND MATERIALS, chapter 4 (8th ed. 2020).

${ }^{63}$ Lea Brilmayer \& Charles Norchi, Federal Extraterritoriality and Fifth Amendment Due Process, 105 HARV. L. REV. 1217, 1217 (1992).
} 
rule because it reflects the legislature's accommodation of other states' possibly conflicting substantive regulations on the subject matter. Such a geographic scope limitation does not reflect the legislature's preference that the substantive rule it has adopted not be applied to conduct or persons beyond the specified scope of the law. Most likely, the legislature would be delighted if the rule that it regards as substantively better were applied to conduct or persons beyond its scope. The most that can be said is that the legislature is agnostic about the proper rule to govern cases beyond the statute's specified scope, or is unsure about the suitability of the rule for states with different traditions, different values, or different characteristics. ${ }^{64}$ These are the sorts of considerations that typically underlie choice-of-law rules. ${ }^{65}$

French scholar Patrick Kinsch offers the following test for distinguishing between internal scope limitations (which he calls self-limiting provisions) from choice-of-law rules:

If we are dealing with a conflict of laws rule that determines the applicability of a norm, the choice is between the application of that norm and the application of the substantive law of a different legal system; if we are dealing with a self-limited law, the choice is between the application of that norm and the application of another norm of the same legal system. ${ }^{66}$

Under this test (which I whole-heartedly endorse), geographic scope limitations are conflict-of-law rules. ${ }^{67}$ While a legislature that enacts an internal scope limitation implicitly leaves conduct or persons that fall outside of the statute's specified scope to

${ }^{64}$ A legislature might have more nefarious reasons for limiting the geographic scope of its statutes. As discussed in Part IV, such geographic scope limitations are very likely unconstitutional.

65 See, e.g., Alex Mills, The Identities of Private International Law: Lessons From The U.S. and EU Revolutions, 23 DUKE J. COMP. \& INT’L L. 45, 472 (2013) (“[O]ne . . fundamental value [underlying private international law] is ... 'justice pluralism'-the acceptance that the questions of private law do not have a single 'correct' answer, that different societies are capable of making (and entitled to make) different decisions about such questions, and that in a world of coexisting states those differentiated determinations of the just outcome of a dispute ought to be given at least a degree of accommodation."); Joseph W. Singer, Real Conflicts, 69 B. U. L. REV. 1, 6 (1989) (“[T]he forum should not apply ... forum law if this will significantly interfere with the ability of another state to constitute itself as a normative community and the relationship between the forum and the dispute is such that the forum should defer to the internal norms of the foreign normative community. The forum must determine under what circumstances it is obligated to subordinate its own concerns to the ability of its neighbor to create and enforce a different way of life.").

${ }^{66}$ Patrick Kinsch, L'autolimitation implicite des normes de droit privé materiel, 92 REVUE CRITIQUE DE Droit Internationale Privé 403, 410 (2003) (emphasis in original) (my translation). Kinsch attributes this test to K. Schurig, Kollisionsrecht und Sachrecht, Berlin 1981, p. 61 et passim, who in turn attributes his analysis to F. Kahn, Gestetzkollisionen. Ein Beitrag zur Lebre des internationals Privatrechts, JEHERINS Jb 40 (1891)).

${ }^{67}$ I discuss Kinsch's application of this test to geographic scope limitations in Part IV. 
be governed by another law of that state, a legislature enacting a geographic scope limitation has not done so. It has not expressed a preference that cases outside the statute's scope should be governed by a different substantive rule. The state does not have a law for cases lacking the specified connection to the state. This is certainly the case when the geographic scope limitation reflects the jurisdictional hook that gives the state the power to makes its law applicable to the case under international law or under the U.S. Constitution. With respect to these sorts of geographic scope limitations, the enacting state lacks the power to prescribe a rule for cases beyond the statute's scope. When the enacting state selects a jurisdictional hook for reasons of inter-state or international comity, it is equally the case that the enacting state has not enacted a different substantive rule for cases beyond the statute's specified geographic scope. The geographic scope provision merely indicates that, as far as the enacting legislature is concerned, cases beyond the statute's specified scope should be governed by the law of another state. It is for this reason that the provision is best understood as a choice-of-law rule.

A geographic scope limitation is undoubtedly a less complete choice-of-law rule than a rule that goes on to specify which other state's law does govern the case. It is a "unilateral" choice-of-law rule in the sense that it does not specify which other state's law applies. But it is nonetheless a choice-of-law rule in the sense that its sole purpose is to convey the legislature's view that, for cases beyond the specified scope of the statute, the law of some other state should govern. If the message the legislature intended to send in enacting such a provision is that cases beyond the geographic scope of the law should be governed by the law of another state, then a court that seeks to comply with the legislature's wishes will resolve the case according to the law of another state. Thus, if State B's choice of law rules select the law of State A as the applicable law, and State $\mathrm{A}$ has a statute on the relevant issue that contains a geographic scope limitation rendering it inapplicable to the case at hand, then a State B court wishing to be faithful to the instruction State A's legislature intended to give would resolve the case by applying the law of a state other than State A. But that is renvoi, which both restatements prohibit in most cases Similarly, if a contractual choice-oflaw clause selects the law of State A to govern the contractual relationship, and State A has a statute addressing the relevant issue that is inapplicable because of a geographic scope limitation, then a court wishing to be faithful to the legislature's intent would resolve the case by applying the law of another state. But to do so would be to interpret the contractual clause to select State A's whole law, which both restatements presume was not the parties' intent.

Professor Morris called a geographic scope provision a "bastard hybrid," and his characterization is apt: in outward form, it is a limit on the reach of the enacting state's substantive law, but in purpose and intended effect, it is a choice-of-law rule. Morris recommended that legislatures use "general" choice-of-law clauses, rather than 
unilateral ones. Once we acknowledge that geographic scope limitations are meant to function as choice-of-law rules, however, these provisions can be understood in a way that dissolves Morris' distinction: a geographic scope limitation indicating that a statute addressing a tort issue extends to cases in which the injury occurred in the state, for example, could be understood to express the legislature's view that this tort issue should be governed by the law of the place of injury. ${ }^{68}$ So understood, the provision would function in the same way as what Morris describes as a general choice-of-law provision-for example, one that provides that tort issues should be governed by the law of the place of injury. ${ }^{69}$ Even so, Morris' recommendation to avoid unilateral choice of law rules still makes a lot of sense. Using general choice-of-law provisions rather than geographic scope provisions would avoid the confusion surrounding the latter clauses that stem from their formulation as rules of substantive scope. In any event, the two types of provisions should be understood to serve the same function.

\section{DifFiCUlties OF CLASSIFICATION}

Lord Collins wrote that "it is not always easy to distinguish between unilateral conflict rules and self-limiting provisions," and he claimed that "[no] writer [has] succeeded in formulating a satisfactory test for distinguishing between them." "The reporters of the Third Restatement have cited this difficulty as an additional reason not to distinguish between geographic scope limitations and internal scope limitations. ${ }^{71}$ I agree that it is difficult to find a rational test for the distinction Lord Collins sought to draw. He included among "self-limiting provisions" those that would limit the scope of a statute to British ships or British citizens, and he distinguished these from a provision limiting the scope of the Marriage Act to "person[s] domiciled in Scotland," which he classified as a unilateral choice-of-law rule. All three of these would be geographic scope limitations, and thus choice-of-law rules, under my definition.

The distinction I seek to draw is clearer, and the examples given by Lord Collins would unambiguously fall on one side of the line or the other. As explained

68 Accord Hay, supra note 2, at 134 (1982): "[A] self-limited rule of substantive law does have aspects of a conflicts rule and can perform a broader function .... Thus, a rule of local law can often be generalized. An example is the rule against perpetuities: its application may be regarded as limited to property situated in the forum or be generalized into a choice-of-law rule that situs law (or the law applicable to succession in a particular case) governs the descent and distribution of the decedent's property."

69 See supra TAN 39.

70 Dicey, Morris, \& Collins, Conflict of Laws, Vol. 1 (14th ed. 2006), p. 23, 9 1-051.

${ }^{71}$ Third Restatement, supra note $21, \$ 1.03$ comment b. ("Administration would be difficult because it is not clear how to distinguish between scope restrictions that would be excluded and those that would not be. (Some restrictions, such as a cause of action limited to a particular city, would not be excluded.)"). 
in Part II, a geographic scope limitation is one that limits the scope of a substantive rule to conduct or persons having some specified connection to the enacting state. An internal scope limitation is a limitation that would apply to the purely local case, one in which all of the conduct took place in the enacting state and all the parties were principally affiliated with that state. In the case of internal scope limitations, cases beyond the statute's specified scope are governed by another law of the enacting state. In the case of geographic scope limitations, cases beyond the statute's specified scope are governed by the law of another state.

Under this test, Lord Collins' example of a provision limiting the reach of a statute to British citizens or British ships would be a geographic scope limitation. The other examples Lord Collins gave of "self-limiting provisions" would all be internal scope limitations, as I define the term. The easiest to classify are the provisions specifying that the statutes apply "on Sundays, or during the close season for various classes of game birds, or to certain kinds of employees." In the purely internal case, there are other laws of the same state that apply on days other than Sunday, or outside the close season, or to other kinds of employees.

Lord Collins included among "self-limiting provisions" one that limits the statute's applicability to "the capital city," 72 and the Third Restatement cites the difficulty of classifying a statute establishing a "cause of action limited to a particular city" as a reason for rejecting the distinction. ${ }^{73}$ Under my definition, this would be an internal scope limitation. An English statute whose application is limited to "the capital city" leaves cases in which all of the parties are from England and all of the conduct occurred elsewhere in England to be governed by another law of England. If another state's courts, under the forum's choice-of-law rules, concluded that a dispute was to be governed by English law even though the conduct did not occur in England (for example, if the case involved a contract with a choice-of-law clause selecting English law), the court would apply that statute if the conduct occurred in a capital city (such as Paris), while it would apply the law that applies elsewhere in England if the conduct did not occur in a capital city. The same would be true if the statute specified that it applied to conduct in parks, or in a swampy region, or above a certain altitude. Tricky issues of interpretation or application may arise, ${ }^{74}$ but these are not insuperable.

Posing greater challenges are certain scope-limiting provisions that I would call mixed scope limitations. Consider the law at issue in the well-known case of McDermott,

\footnotetext{
72 See id.

73 See supra note 71.

74 For example, should a statute specifying that it applies in London be understood to mean that it applies in "the capital city" for purposes of a case in which English law is applicable but the conduct took place in another capital city?
} 
Inc. v. Lewis. ${ }^{75}$ Lewis involved a Panamanian law applicable to "corporations registered in the National Securities Commission [of Panama] and those whose shares are sold on the [Panamanian] market." ${ }^{76}$ Is this a geographic scope limitation or an internal scope limitation? It has aspects of both. The provision requires a connection to Panama, but it also imposes a limit that would be applicable to Panamanian corporations operating entirely in Panama: the prohibition applies only to corporations registered with a governmental agency and sold on the market. A mixed scope limitation such as this should be dissected into two separate limitations. Insofar as the provision requires that the corporation be properly registered and that its shares be sold on the market, the limitation is an internal scope limitation. That is a limitation that even wholly Panamanian corporations operating entirely in Panama must satisfy to be covered by the law. But insofar as the provision limits the law's scope to corporations registered in Panama and its shares sold on the Panamanian market, the provision is a geographic scope limitation. Thus, if the forum's choice-of-law rules for some reason required the application of Panamanian law to a Delaware corporation, the court would, under my analysis, ask whether the corporation was properly registered (in Delaware) or its shares sold on the market (in Delaware or elsewhere). These two requirements limit the statute's internal scope. If the Delaware corporation was not registered or its shares were not sold on a market, the court would apply the Panamanian law that applies to Panamanian corporations that are not registered or whose shares are not sold on the market. But the requirement that the corporation be registered in Panama or its shares sold in Panama is a geographic scope limitations and hence a choice-of-law rule. If another state's choice-of-law rules selected Panamanian law as applicable to this case, it would disregard the provision insofar as it requires the link to Panama (unless the forum's choice-of-law rules permit renvor).

Geographic scope limitations attached to a federal law are subject to the same analysis, although they pose some distinct issues. Consider a federal securities statute that prohibits securities fraud but has a scope limitation providing that the it applies to fraud in the sale of securities traded or otherwise sold in U.S. markets. ${ }^{77}$ This is a mixed scope limitation very similar to that contained in the Panamanian law discussed above. To the extent the scope provision limits the statute's scope to securities having the specified connection to U.S. markets, it is a geographic scope limitation. It conveys the legislator's view that securities traded or sold in foreign markets should be subject to foreign securities laws. The choice-of-law function of geographic scope limitations in federal statutes will often be hidden because, if the case is pending in a federal court, the court's jurisdiction will usually be limited to the federal claim. ${ }^{78}$ Thus, if the court

75531 A.2d at 208.

${ }^{76} \mathrm{Id}$.

77 Cf. Morrison v. Nat'l Austl. Bank Ltd., 561 U.S. 247 (construing federal securities laws as subject to a similar geographic scope limitation).

7828 U.S.C. $\int 1331$ (conferring jurisdiction of federal courts over cases arising under federal law). 
concludes that the case before it lacks the requisite link to the United States, it will usually dismiss the case for failure to state a claim without going on to consider whether the claimant can prevail under foreign law. ${ }^{79}$ But the fact that the court in these cases does not explicitly frame the issue as a choice between U.S. and foreign law should not obscure the geographic scope limitation's choice-of-law function. As the Supreme Court has repeatedly noted, a principal purpose of the rules it applies to determine the extraterritorial scope of federal statutes is "to protect against unintended clashes between our laws and those of other nations which could result in international discord." ${ }^{80}$ As the Court put it in Lauritzen v. Larsen, the Court's approach to determining a federal statute's extraterritorial scope is based on "considerations of comity, reciprocity, and long range interest" and seeks to "define the domain that each nation will claim as its own." ${ }^{\prime 1}$ As noted above, these are the sorts of considerations that underlie choice-of-law rules.

In addition to serving a horizontal choice-of-law function, geographic scope limitations in federal statutes may also serve a vertical choice-of-law function. With respect to any federal statute, there will commonly be a question about whether the statute preempts state law on the topic. With respect to a statute having an express or implied geographic scope limitation, there may in addition be a question about whether the federal statute preempts the authority of U.S. states to extend their laws on the matter to cases having foreign connections. For example, a statute creating a federal remedy for securities fraud may preempt the field of securities fraud, thus displacing any state regulation of the subject. Even if it does not, however, there may be a question whether Congress' decision to defer to other nations regarding securities traded or sold in foreign markets implicitly preempts U.S. states from extending their remedies for securities fraud to fraud in the sale of securities traded or sold in foreign markets. Congress' determination that deference was owed to foreign legislative prerogatives in such cases could be interpreted as an implicit preemption of the state's legislative authority over such cases. The case for such preemption is bolstered by the

\footnotetext{
${ }^{79}$ The federal courts do have supplemental jurisdiction over cases based on state or foreign law in certain circumstances, but, if the claim is dismissed on the pleadings because the case lacks the requisite link to the United States, the court will typically decline to exercise supplemental jurisdiction. 28 U.S.C. \1367 (c)(3) (2012); see, e.g., Artis v. District of Columbia, 138 S. Ct. 594, 597-98 (2017) ("When district courts dismiss all claims independently qualifying for the exercise of federal jurisdiction, they ordinarily dismiss as well all related state claims."). If the court has diversity or alienage jurisdiction, the court could entertain claims based on state or foreign law but will not entertain claims based on foreign public law, including tax or regulatory laws. 28 U.S.C. $\$$ 1332 (2018); see William Dodge, Breaking the Public Law Taboo, 43 HARV. INT' L.J. 161, 161 \& n.3 (2002) ("When the foreign law at issue is public — criminal, tax, antitrust, or securities law, for example-courts will neither apply that law to decide a case nor enforce the decision of a foreign court applying that law" (citing cases)).

${ }^{80}$ E.E.O.C. v. Arabian Am. Oil Co. (Aramco), 499 U.S. 244, 248 (1991).

${ }^{81}$ Lauritzen v. Larsen, 345 U.S. 571, 582 (1953).
} 
Constitution's assignment of foreign relations powers mainly to the federal government. ${ }^{82}$ This possible vertical choice-of-law implication of geographic scope limitations has largely been unexplored in the cases and the literature. ${ }^{83}$

\section{Alternative Understandings of GeOgRAPHiC SCOPE Limitations}

In Part II, I argued that geographic scope limitations should be understood to have solely a choice-of-law function: a legislature enacting such a limitation is telling us that cases beyond the statute's specified scope should be governed by the law of a different state. Such provisions differ from internal scope limitations in that the latter leave excluded cases to be governed by a different substantive rule of the same state, while the former do not. A state with a scope-limited statute has no law for cases beyond the statute's specified scope.

The Third Restatement takes a different view. It sees no difference between internal and geographic scope limitations, apparently viewing both as establishing a substantive rule for cases within the statute's specified scope and leaving cases beyond the statute's specified scope to be governed by another law of that state. According to the Third Restatement, a state's internal law is "the body of law which the courts of that state apply when they have selected their own law as the rule of decision for one or more issues." ${ }^{\prime \prime}$ Since the Third Restatement regards geographic scope limitations as parts of the state's internal law, its position appears to be that, for cases beyond a statute's specified geographic scope, the enacting state does have a "rule of decision" that is part of its "body of law." In other words, the Third Restatement appears to understand a geographic scope limitation as telling us that cases beyond the statute's specified geographic scope are governed by a different substantive rule of the same state. ${ }^{85}$

82 See, e.g., Crosby v. Nat'l Foreign Trade Council, 530 U.S. 363 (2000); Hines v. Davidowitz, 312 U.S. 52 (1941). See generally Carlos M. Vázquez, W/bjither Zschernig?, 46 VILL. L. REV. 1259 (2001).

${ }^{83}$ But cf. Carlos M. Vázquez, Things We Do With Presumptions: Reflections of Kiobel v. Royal Dutch Petroleum, 89 Notre Dame L. Rev. 1719, 1728 (2014) (raising the question whether the Supreme Court's holding that the federal common law cause of action for alien torts as not having extraterritorial effect implicitly preempts the power of states to give extraterritorial effect to state causes of action for alien torts).

84 Third Restatement, supra note 21, \$1.03(1).

85 This conclusion also seems to follow from the Third Restatement's treatment of renvoi. As noted, the Third Restatement prohibits renvoi in most cases by specifying that, when a state's choice-oflaw rules direct application of another state's law, its courts will apply that state's "internal law." See supra note 28 and accompanying text. Yet the Third Restatement defines "internal law" as including a state's geographic scope limitations. See supra TAN 21. If a geographic scope limitation were understood merely to convey the legislature's view that another state's law should be applied (the state having no law for cases beyond the statute's geographic scope), then the Third Restatement's instruction to courts to take that geographic scope limitation into account would be 
This is, indeed, how courts have interpreted such limitations in cases that the Third Restatement cites with approval. ${ }^{86}$ Budget Rent-a-Car System, Inc. v. Chappell is a good example. ${ }^{87}$ This case involved section 388 of New York's Vehicle and Traffic Law, which established that owners of vehicles are vicariously liable to persons injured by the vehicle. ${ }^{88}$ This law included a geographic scope restriction specifying that it applied to "[e]very owner of a vehicle used or operated in this state." 89 In deciding whether to apply New York or Michigan law to the case, the court first identified the content of the laws of both states. Taking the approach advocated by the Third Restatement, the court relied on the scope restriction in determining the content of New York law on this issue. The court concluded that New York had a law for vehicles that had been "used or operated" within New York (vicarious liability) and that it also had a law for vehicles not "used or operated" in New York (no vicarious liability). Because the vehicle before the court had not been used or operated in New York, the court concluded that, "under New York law, Budget is not vicariously liable to Chappell." $" 90$ The court then went on to determine whether to apply this law of New York or to apply Michigan law instead (which provided for vicarious liability). ${ }^{91}$ If the court had treated the scope limitation as a choice-of-law rule, it would have determined (a) that the only substantive law New York had on the issue was one imposing vicarious liability (the same substantive law as Michigan's), and (b) that the geographic scope limitation merely reflected the New York legislature's willingness to leave it to other states to address the vicarious liability of owners of vehicles that had not been used or operated in New York. ${ }^{92}$ The court instead concluded that New York did have

inconsistent with its rejection of renvoi. The Third Restatement thus appears to contemplate that the enacting state does have a law for cases beyond the statute's geographic scope. As noted below, the Third Restatement's position appears to be that the enacting state has prescribed nonregulation for cases beyond the statute's geographic scope. See infra TAN 104.

86 See Third Restatement, supra note 21, $\$ 1.03$ comment b.

87 Budget Rent-A-Car System v. Chappell, 304 F. Supp. 2d 639 (E.D. Pa. 2004), rev'd on other grounds, 407 F.3d 166 (3d Cir. 2005).

${ }^{88} \mathrm{Id}$. at 645 .

${ }^{89} \mathrm{Id}$.

${ }^{90} I d$. (emphasis added).

${ }^{91}$ Michigan's law authorizing vicarious liability was subject to a damage cap, but the damage cap was, in turn, subject to an internal scope limitation that, the court held, rendered the cap inapplicable to the case. See id. at 648-50.

${ }^{92}$ If the court had applied the Second Restatement's approach, it would have concluded that New York and Michigan had the same local law (providing for vicarious liability), and it would have grouped the contacts of the two states together and applied that law if no other state has a materially greater interest. See Second Restatement, $\mathbb{1} 145$ comment i, discussed supra note 25. Instead the court concluded that neither state had an interest in having its law applied and wound up denying vicarious liability even though the local law of the two states most closely connected to the dispute authorized vicarious liability. Cf. infra note 97 (discussing apparent absurdity of such a result). 
a law for vehicles not used or operated within New York-a law denying vicarious liability. ${ }^{93}$

This understanding of geographic scope limitations has been expressly adopted by some scholars. For example, as noted above, Patrick Kinsch distinguishes "self-limiting" provisions from choice-of-law rules in that, with respect to the former, the alternative is application of another law of the same state, whereas, with respect to the latter, the alternative is the application of the law of a different state. ${ }^{94} \mathrm{He}$ concludes, however, that geographic scope limitations are "self-limiting" provisions under this test. Kinsch's conclusion must be based on the understanding that, when a legislature has enacted a statute and limited its scope to cases having specified connections to the state, cases that are beyond the specified scope of the statute are to be governed by another law of the same state.

De Nova has defended a similar view. Consistent with the Third Restatement, he took the position that a geographic scope limitation is not a choice-of-law rule, and that a court giving effect to such a limitation is not engaging in renvoi. ${ }^{95}$ De Nova explained his views through a critique of the famous New York decision in Babcock $v$. Jackson. ${ }^{96}$ Babcock was one of the first cases to depart from the traditional lex loci delicti choice-of-law rule for tort cases, under which the applicable law is that of the place of injury. In its place, the court adopted a version of Currie's interest analysis. Two New Yorkers took a day trip by automobile to Ontario, where they were involved in an accident. The passenger was injured and sued the driver in the New York courts for negligence. Ontario had a guest statute, which barred tort recovery by a guest against his host. New York, on the other hand, allowed recovery by guests against negligent hosts. Under the lex loc delicti rule, the law of Ontario would have applied, and recovery would have been defeated. Consistent with Currie's approach, however, the New York court sought to ascertain the purpose of Ontario's guest statute, and it determined that the law's purpose was to protect hosts from ungrateful guests and to protect insurance companies from collusive suits. Because the host in the case was from New York and

\footnotetext{
${ }^{93}$ On appeal, the Third Circuit determined that the vehicle involved in this case was covered by section 388, which the New York Court of Appeals had construed more broadly. Budget Rent-ACar System v. Chappell, 407 F.3d 166, 172 (3d Cir. 2005). But the appellate court, too, seemed to regard the geographic scope limitation a bearing on whether New York law established or denied vicarious liability, rather than as a choice-of-law rule. Indeed, the Third Circuit criticized the New York Court of Appeals for its "unfortunate ... conflat[ion] [of] the substantive law question (the scope of the statute) with the choice-of-law question (the extent of New York's interest in applying the statute)." Id. at 173. Under the analysis defended in this article, the New York Court of Appeals examined the question correctly.

${ }^{94}$ See supra TAN 66

${ }^{95}$ Rodolfo de Nova, Historical and Comparative Introduction to Conflict of Laws, 118 RECUEIL DES COURS 438, 533 (1966).

96191 N.E.2d 279, 286 (N.Y. 1963).
} 
the automobile was insured there, the court concluded that the purpose of Ontario's law would not be advanced if its guest statute were applied to the case. The purpose of New York's law permitting recovery, on the other hand, was to ensure that injured guests were compensated by negligent hosts. Because the injured guest in this case was from New York, the court concluded that New York did have an interest in having its law applied. Thus, in Babcock, the court employed a purposive analysis to determine the geographic scope of the laws of Ontario and New York. The court concluded that the Ontario law did not extend to this case because its purposes would not be advanced and that New York's law did extend to this case because its purposes would be advanced. Because New York's law extended to the case and Ontario's did not, the court resolved the case under New York law.

De Nova agreed with the result in the case, and he agreed with Currie's view that the first step in the analysis should be to determine the geographic scope of each state's law through interpretation. But he argued that this did not require a departure from the traditional lex loci delicti rule. The court should have applied the law of Ontario, but, consistent with its purposive analysis of the geographic scope of the Ontario guest statute, it should have concluded that the guest statute prohibiting recovery by a guest against his host did not extend to cases in which the host was from another state. In other words, according to De Nova, a purposive analysis leads to the conclusion that Ontario's guest statute is subject to an implicit geographic scope limitation: it applies only to cases in which the host is from Ontario (or the car was insured in Ontario). But this means, in De Nova's view, that Ontario has a law for cases in which the host was not from Ontario: in such cases, Ontario law permits recovery by a guest against the host. ${ }^{97}$ In his critique of Babcock, De Nova examined geographic scope limitations read into a statute through interpretation. His analysis applies a fortiori to geographic scope limitations expressly included in the statute. ${ }^{98}$

${ }^{97}$ In addition to the problems discussed below, notice another absurdity produced by this analysis. In his view, a court should apply Ontario law when the accident occurred there, but it should read Ontario law to permit recovery by a guest against a host when the host is not from Ontario. He would apparently reach this conclusion even if the host and guest were from a state that also has a guest statute. That the Third Restatement's approach would require the court to reach a conclusion at odds with the substantive law of all relevant states is another reason to reject it. Even though scholars and courts have described this result as "absurd," Norlin Corp., v. Rooney, Pace Inc., 744 F.2d 255, 264 (2d Cir. 1984), "whimsically unjust," David F. Cavers, The Two "Local Law" Theories, 63 HARV. L. REV. 822, 828 (1950), and "preposterous," Robert A. Leflar, True "False Conflicts," Et Alia, 48 B.U. L. REV. 164, 171 (1968), the reporter of the Third Restatement regards the result as an "undeniable advance" in choice-of-law thinking. Roosevelt, Resolving Renvoi, supra note12, at 1884, 1885. I examine this issue in Vázquez, Choice of Law Step Zero (unpublished manuscript).

98 As discussed below, see infra TANs 113-116, Currie would not have agreed with De Nova's conclusion that Ontario's geographic scope limitation meant that Ontario had a law permitting recovery for cases beyond the guest statute's geographic scope. Currie appears to have regarded geographic scope limitations as choice-of-law rules. Indeed, Currie's interest analysis would make 
The claim that a legislature specifying the geographic scope of a statute means that excluded cases are to be governed by a different law of that state poses severe difficulties. Consider a statute enacted by the State A legislature comprehensively regulating franchises and specifying that it extends to franchises operating in State A. According to the position expressly adopted by Kinsch and De Nova, and apparently endorsed by the Third Restatement, State A has a law for franchises operating outside of State A. If so, one must ask: What is the content of State A's law for out-of-state franchises?

One possibility is that out-of-state franchises are governed by State A's common law. ${ }^{99}$ If so, would that be State A's common law frozen in time as of the date of the statute's enactment, or would it be State A's common law as the State A courts might develop it over time? The former approach would risk holding out-ofstate franchises to an anachronistic rule that State A and most (perhaps all) other states had long since abandoned. The latter approach would burden the State A courts with the obligation to continue to develop the state's common law for cases having only a limited connection to the state. The legislature is unlikely to have intended either approach.

Moreover, the state's common law can supply the state's substantive law for cases beyond the geographic scope of the statute only if the common-law rule was not also subject to a geographic scope limitation. A central tenet of Currie's theory was that the courts should use interest analysis to determine the geographic scope of common-law rules as well as statutes. ${ }^{100}$ This is, in fact, what the court did in the Budget Rent-a-Car case, discussed above. Having determined that section 388 did not extend vicarious liability to owners of vehicles not used or operated in New York, the court concluded that the law of New York applicable to the owners of such vehicles was the common law of New York before the New York legislature enacted section 388, which

little sense if he understood implicit geographic scope limitations as indicating that the state had a different substantive law for cases beyond the law's scope. He concluded that if the forum state had no interest in having its law applied to the case, the court should apply the law of a state that did have an interest in having its law applied. To the extent he inferred a geographic scope limitation from a state's lack of interest in having its law applied, he appears to have understood that the state has no law on the relevant issue for cases beyond the statute's geographic scope.

99 This is the approach favored by Professor Sedler. See Sedler, supra note 2, at 35 (1976). Professor Lipstein, however, concluded that "[s]uch a solution displays a touch of the unreal." Lipstein, supra note 37 , at 893 .

100 Brainerd Currie, Selected Essays on the Conflict of Laws 627 (1963) (“[T]he method I advocate is the method of statutory construction, and of interpretation of commonlaw rules, to determine their applicability to mixed cases."). 
did not provide for vicarious liability. ${ }^{101}$ The court next engaged in interest analysis, asking whether New York had an interest in having its no-vicarious-liability commonlaw rule applied to this case, and the court answered that question in the negative on the ground that applying its law to this case would disadvantage a New York resident. ${ }^{102}$ Notably, the court did not ask the next question which would arise if geographic scope limitations are understood the way Kinsch, De Nova, and (apparently) the Third Restatement understand them: What is New York's law for cases beyond the scope of both section 388 and New York's common law no-vicariousliability rule? The court either did not realize that the point of the first step of interest analysis is to determine the implicit geographic scope of New York's common law rule, or it understood that the implicit scope limitation derived from interest analysis functioned as a choice-of-law rule signifying that the dispute should be governed by the law of another state. If the court did understand that the implicit geographic scope limitation it read into the common-law rule operated as a choice-of-law rule, it overlooked the fact that the explicit geographic scope limitation in section 388 functions in exactly the same way.

De Nova's analysis of Babcock $v$. Jackson suggests a different way to determine the content of a state's law for cases beyond the geographic scope of a statute. He concluded that, because Ontario's statute prohibiting recovery did not extend to injuries caused by out-of-state hosts, Ontario law permitted recovery against out-of-state hosts. By the same logic, we could say that the law of State A for franchises operating outside of State A is that all is permitted-anything goes. This appears to be how the Third Restatement understands geographic scope limitations. In discussing contractual choice-of-law clauses, the Third Restatement notes that "[w] hen the parties select a scope limited law that excludes them or their transaction, ... the effect is not to opt in to one rather than another State's regulatory regime but rather to opt out of regulation entirely." 103 The Third Restatement thus appears to understand a State A franchise law that extends only to franchises operating in State A as prescribing non-regulation for out-of-state franchises. ${ }^{104}$

This is an even less plausible interpretation of the the scope limitation than one that leaves cases beyond the statute's scope to the governed by the state's common law. Statutes are usually thought to build upon the state's common law, changing it where necessary. ${ }^{105}$ Thus, cases beyond the scope of a statute would presumptively

101 See Budget Rent-A-Car System v. Chappell, 304 F. Supp. 2d 639, 650 (E.D. Pa. 2004), rev'd on other grounds, 407 F.3d 166 (3d Cir. 2005).

102 Id.

103 Third Restatement, supra note 20, \$ 8.04 comment g.

104 But cf. infra note 108 (discussing ambiguity in Third Restatement's position).

105 For a classic statement of this view, see RICHARD FALLON ET AL., HART \& WECHSLER's THE FEDERAL COURTS AND THEE FEDERAL SYSTEM at 489 (7th ed. 2015): "Congress acts . . . against 
remain governed by the common law. ${ }^{106}$ To conclude that State A's law for out-ofstate franchises is that all is permitted would require an interpretation of the statute as preempting the field, displacing the preexisting common law for cases both within and beyond the statute's specified scope, and prescribing non-regulation as the law of the state for cases beyond the statute's specified geographic scope. It is very unlikely that this is what the legislature had in mind when it comprehensively regulated franchises but limited the statute's scope to in-state franchises. It is far more likely that the legislator did not intend to establish a different rule for out-of-state franchises, but instead meant to leave them to be governed by the law of other states.

The foregoing analysis rests on what may seem to be a very subtle distinction between State A having a law permitting X and State A having no law prohibiting X in cases lacking the specified connection to State A. The distinction is indeed subtle, but it is important. If the United States has a federal statute prohibiting fraud in the sale of securities but limits the statute's scope to securities sold in the United States, ${ }^{107}$ do we conclude that the U.S. has a law permitting frand in the sale of securities sold on foreign markets? If New York has a law prohibiting murder but limits the scope of the law to murders taking place within New York, does that mean that New York has a law permitting murders that take place in other states? Purely from the standpoint of legislative intent, such a reading of the geographic scope limitation seems implausible. The more sensible reading of such laws is that the legislature has left the matter to the laws of other states. If so, then, under Kinsch's test and mine, the geographic scope limitation is a choice-of-law rule. ${ }^{108}$

the background of the total corpus juris of the states in much the same way that a state legislature acts against the background of the common law, assumed to govern unless changed by legislation." ${ }^{106} \mathrm{I}$ argued in the previous paragraph that this construction of a geographic scope limitation is unlikely to have been intended by the legislature. The legislature is more likely to have meant that cases beyond the statute's specified geographic scope are to be governed by the law of a different state. My point here is that the legislature is even less likely to have intended to preempt the field and prescribe non-regulation as the state's law for cases beyond the statute's specified geographic scope.

107 Cf. Morrison v. Nat'l Austl. Bank Ltd., 561 U.S. 247 (2010) (interpreting U.S. securities statute that way).

108 In the same paragraph in which the Third Restatement asserts that selection of the law of a state with a scope-limited statute that does not extend to the subject matter of the contract amounts to choosing non-regulation, see supra TAN 103, the Third Restatement acknowledges that a law containing a geographic scope limitation reflects "deference to the regulatory authority of other States." Additionally, some of the Third Restatement's comments on contractual choice-of-law clauses suggest that a state with a scope-limited statute does not purport to exercise regulatory authority at all for cases beyond the statute's scope. See, e.g., $\$ 8.04$ comment b Illustration 3 (State C Act limited in scope to transactions within State C "attaches no legal consequences to transactions outside of State C"). Insofar as the Third Restatement understands that selecting the law of State $C$ as applicable means, for cases beyond the geographic scope of the statute, opting for non-regulation, the Third Restatement appears to equate the absence of a State C statute 
Moreover, understanding geographic scope limitations as establishing a different rule of the enacting state to govern cases beyond the statute's specified scope poses significant constitutional problems. Consider a statute that establishes a remedy for certain types of injuries but limits its scope to injuries suffered by domiciliaries of the state. ${ }^{109}$ It is conceivable that the legislature, in enacting the geographic scope limitation, did not mean to leave the remedy for injuries suffered by non-domiciliaries to be governed by the law of their domicile. The legislature may instead have wanted that non-domiciliaries be denied a remedy. In other words, the legislature may have meant to provide an advantage to domiciliaries and to disadvantage non-domiciliaries. We might call this a protectionist law. ${ }^{110}$

That some geographic scope limitations may reflect a desire to protect only in-state persons or businesses cannot be discounted. The legislation process is often characterized by logrolling and rent-seeking activity in which, for obvious reasons, outof-staters are likely to be at a disadvantage. Some courts confronted with geographic scope limitations have candidly recognized that the legislature, in enacting a scopelimited law, intended to limit the statute's benefits to residents or domiciliaries. ${ }^{111}$ Even if the legislature did not intend to extend the benefits of the law to out-of-staters, however, it very likely meant to relegate out-of-staters to the law of their home states, rather than to subject out-of-staters to the common-law rules that the legislature was abandoning for in-staters, or to establish a special laissez-faire regime for out-of-staters. If the legislature was not inhibited by doubts about their power to establish special legal rules for out-of-state persons or conduct, it would, one hopes, have been deterred from doing so by the fear that other states would retaliate by establishing a special, unfavorable legal regime for non-domciliaries. In any event, as this Part will show, a statute that enacts one (favorable) rule for domiciliaries of the state and relegates nondomiciliaries to a different, less favorable rule of that state will in most cases be unconstitutional, as would (albeit for different reasons), a statute that enacts one rule

prohibiting something with the existence of a State C law permitting it. This is a correct understanding of internal scope limitations but, as explained in the text, it is not a correct understanding of geographic scope limitations.

109 See NussBAuM, supra note 31, at 72 (citing, as an example of a spatially-conditioned internal rule, "an exemption statute [that] reserve[s] its benefits to local residents.)

110 See Larry Kramer's analysis, discussed infra TAN 118.

111 See, e.g., Highway Equip. Co. v. Caterpillar, Inc., 908 F.2d 60, 63 (6th Cir. 1990) ("When it reenacted the [Illinois Franchise Disclosure] Act, the Illinois legislature 'confirmed that the statute is intended to protect Illinois residents only."'); Bimel-Walroth Co. v. Raytheon Co., 796 F.2d 840, 842-43 (6th Cir. 1986) ("[T]he legislative history of [amendment to Wisconsin Franchise statute] makes it abundantly clear that that the language was intended to ensure that [the statute] would only be applied to Wisconsin dealers, or those geographically 'situated' in Wisconsin, who were the desired beneficiaries of the legislation.") 
for conduct occurring within the state and a different rule of the same state for conduct that takes place outside the state's territory. ${ }^{112}$

Direct support for the conclusion that a statute establishing a different, unfavorable rule for non-domiciliaries would be unconstitutional comes from an unlikely source: Brainerd Currie. Professor Currie's interest analysis has been criticized precisely on the ground that it discriminates against non-domiciliaries. Currie generally assumed that a state was interested in applying its law if the policy advanced by the law would operate in favor of a domiciliary. Thus, on the facts of Babcock $v$. Jackson, if the purpose of the law was to protect injured guests, the state has an interest in applying its law if the injured guest was a domiciliary. For Currie, then, such a law would extend to domiciliaries but not to non-domiciliaries. This disparate treatment of nondomiciliaries has led to charges that Currie's governmental interest analysis discriminates against out-of-staters in violation of the Privileges and Immunities Clause and the Equal Protection Clause of the U.S. Constitution. ${ }^{113}$

The most persuasive rebuttal to this constitutional objection is that the state has not, through its geographic scope limitation, enacted a law denying domiciliaries the benefits of its law. It does not have a law for non-domiciliaries. Instead, the geographic scope limitation tells us that, with respect to non-domiciliaries, it has relegated the issue to the state of that person's domicile. ${ }^{114}$ But, as Currie recognized, this rebuttal rests on the proposition that the enacting state's geographic scope limitation was adopted for reasons of comity and functions as a choice-of-law rule.

As defended by Professor Currie and applied by (most) courts, and contrary to De Nova's analysis, interest analysis does not tell us that the state has a different law for cases beyond the geographic scope of the statute. If the substantive rule in a statute (or common law rule) would not operate in favor of a domiciliary, the court concludes that the state does not have an interest in applying the rule to the case. But

\footnotetext{
112 In some cases involving public benefits, denying the law's benefits to persons lacking specified connections with the state will be constitutional. See infra note 129.

113 See, e.g., Douglas Laycock, Equal Citizens of Equal and Territorial States: The Constitutional Foundations of Choice of Law, 92 Colum. L. REv. 249, 250, 269-70 (1992); John Hart Ely, Choice of Law and the State's Interest in Protecting Its Own, 23 WM. \& MARY L. ReV. 173 (1981). Professor Currie acknowledged and responded to these criticisms in two separate articles. See Brainerd Currie \& Herma Hill Schreter, Unconstitutional Discrimination of Laws: Privileges and Immunities, 69 YALE L. J. 1332 (1960); Brainerd Currie \& Herma Hill Schreter, Unconstitutional Discrimination in Conflict of Laws: Equal Protection, 28 U. CHI. L. REV. 1 (1960).

114 Even if so understood, Currie's interest analysis is vulnerable to the objection that it discriminates against non-domiciliaries because it relegates them to their home state's law only when dong so disadvantages them. See Lea Brilmayer, Interest Analysis and the Myth of Legislative Intent, 78 Mich. L. REV. 392, 415 (1980). My point, though, is that Currie's approach is less objectionable if understood as a choice-of-law rule (which is how Currie understood it).
} 
the court does not conclude that the state is interested in not having the rule applied to the case. Assume that Ontario has a guest statute and New York does not have a guest statute, and the guest is from Ontario and the host is from New York. A court applying interest analysis, as the court in Babcock applied it, would conclude that neither New York nor Ontario has an interest in applying its substantive rule to the case. But it wouldn't conclude that each state has an interest in not applying its rule. Currie described such a case as an unprovided-for case, and he favored application of forum law in such a case. If each state had an interest in not applying its substantive rule, the case would be a true conflict. Both states would have an interest in applying the other state's substantive law. The fact that Currie regarded this as an unprovided-for case indicates that he did not equate a state's lack of interest in applying its substantive law with a state having an interest in not having its substantive law applied. Thus, Currie would not have agreed with De Nova's characterization of geographic scope limitations as telling us that the enacting state has a substantive rule applicable to cases beyond the scope of the geographic scope limitation, the content of which is different from the rule enacted for cases within the scope of the statute.

Indeed, Currie himself regarded such a law as unconstitutional, as he rested the constitutionality of his approach on the idea that limitations on the scope of state laws were based on comity concerns:

Differential treatment of the citizen and the foreigner ... may ... violate the Privileges and Immunities Clause or the Equal Protection Clause of the Constitution. Yet differential treatment of some sort is essential if laws are to be rationally administered and if the state is to maintain a decent respect for the legitimate spheres of responsibility of other states. $^{115}$

After a comprehensive examination of the constitutional issues, Currie concluded:

[A] classification excluding some citizens of other states may be reasonable if it distinguishes among persons according to whether or not they are so protected by the laws of their home states. The validity of such a classification ... is . . . supported by the consideration that such a classification evinces no provincial or hostile attitude towards citizens of other states, but reasonably distinguishes between those persons who are regarded by their home states as needing special protection and those who are not. ${ }^{116}$

115 Id. at 1324.

116 Id. at 1391. 
In Currie's own view, therefore, scope limitations that extend the benefits of some laws to domiciliaries satisfy the Privileges and Immunities and Equal Protection Clauses when they are based on comity concerns - that is, when their only function is to leave excluded cases to be governed by the law of another state. They violate those clauses when they reflect a desire to deny benefits on the basis of citizenship or residency based on provincialism and hostility to non-domiciliairies. In Currie's view, the latter limitations would contravene the Privileges and Immunities and Equal Protection Clauses.

The same conclusion is supported by Professor Larry Kramer. Kramer argues that the Privileges and Immunities Clause bars distinctions based on state residency when such distinctions are designed "to obtain an advantage for residents at the expense of nonresidents." 117 But distinctions based on state residency are not problematic when they serve a "substantial nonprotectionist objective." 118 Geographic scope restrictions that limit the benefit of state laws to residents are generally permissible when "the justification for limiting the scope of [such] laws ... is comity." In such cases, the scope limitation "is a means of accommodating the interests of other states," is the central purpose of the privileges and immunities clause." 121 "A state may withhold the benefits of its law [from nonresidents] in order to apply the law of another interested state, but not otherwise."122 Thus, Kramer, like Currie, concludes that states do not violate the Privileges and Immunities Clause when they restrict the scope of their laws to domiciliaries if they do so out of deference to the legislative authority of the state of domicile. But both would conclude that the geographic scope restriction would be unconstitutional if meant to deny non-domiciliaries an advantage granted to domiciliaries. A fortiori, a geographic scope provision understood to establish an unfavorable rule for nondomiciliaries as the law of the enacting state would be unconstitutional.

Currie's and Kramer's constitutional analyses would not address the validity of scope limitations that draws a distinction based on the place where certain events occurred rather than the residency or domiciliary status of persons. Consider a State A statute establishing a remedy for certain types of injuries which has a scope provision specifying that it applies to injuries suffered in State A. If the statute were understood to also establish a no-remedy rule for injuries suffered outside of State A, it would not violate the Privileges or Immunities Clause-but it would likely violate the Due

117 Larry Kramer, The Myth of the "Unprovided-For" Case, 74 VA. L. REV. 1045, 1066 (1989).

118 Id. at 1067.

${ }^{119} \mathrm{Id}$.

${ }^{120} \mathrm{Id}$.

121 Id. at $1067-68$.

122 Id. at 1068. 
Process Clause. Under the Due Process Clause, a state may extend its law to a dispute if it has "a significant contact or significant aggregation of contacts, creating state interests, such that choice of its law is neither arbitrary nor fundamentally unfair." 123 Facially, a law denying relief based solely on the fact that the injury did not occur in the state would appear to violate that standard. With respect to injuries suffered outside the state, the applicability of the state's no-remedy rule would turn on the absence of contacts with the state. ${ }^{124}$

Of course, there may be cases in which the injury did not occur within the state but the state still has sufficient contacts to make its law applicable consistent with the Due Process Clause. In our hypothetical, perhaps the injury did not occur in State A, but the conduct causing the injury occurred in State A. Does the hypothetical State A statute satisfy the Due Process Clause's "significant contacts" requirement as applied to cases in which there are other contacts sufficient to satisfy Due Process? Perhaps it would, but an "as applied" analysis reveals a distinct Due Process problem: the scope limitation would be arbitrary or irrational. ${ }^{125}$ As applied to our hypothetical, State A law establishes a remedy if the injury occurred in State A but establishes a no-remedy rule if the injury occurred in State B but the conduct causing the injury occurred in State A. It is difficult to conceive of a rational and legitimate policy that would be advanced by such a law. Comity would be a valid reason to limit the scope of the law to cases in which the injury occurred in State A, but a limitation based on comity would merely reflect a preference that the remedy for out-of-state injuries be governed by the law of other states (which would likely also confer a remedy). There may be other valid reasons to draw distinctions according to the location of events. For example, a statute treating out-of-state cases more favorably because of the added difficulty of litigating from a greater distance would be rational. ${ }^{126}$ More generally, a state might validly decide to establish a special substantive rule for multi-state situations to address special problems that arise in such contexts that do not arise in a purely local case, as

\footnotetext{
123 Allstate Ins. Co. v. Hague, 449 U.S. 302, 313 (1981). See also id. at 332 (Powell, J., dissenting) (noting that the Due Process Clause invalidates a state's application of its own law "when there are no significant contacts between the state and the litigation").

124 The district court in Budget Rent-a-Car noted the Due Process problems with extending New York's vicarious liability law to a case having scant connections with New York, 304 F. Supp. 2d at 647. But the court overlooked the Due Process problems with its conclusion that New York had a different law for such cases_one insulating the owner from vicarious liability.

125 See Nebbia v. New York, 291 U.S. 502, 536-37 (1934) (listing cases where "the requirements of due process were not met because the laws were found arbitrary in their operation and effect").

126 This would be the case with respect to one example of a spatially-conditioned internal rule given by Nussbaum: "a statute of limitation . . provid[ing] special periods for action on documents executed abroad." Nussbaum, supra note 31, at 71 (citing Val Platz Brewing Co. v. Industrial Comm'n, 201 Wisc. 474, 230 N.W. 622 (1930)).
} 
Professor von Mehren proposed. ${ }^{127}$ But a state that establishes as its special rule for conduct occurring abroad an anachronistic common law rule that it has displaced for local cases, or prescribes "non-regulation" for such cases, would very likely be acting arbitrarily or irrationally.

The Privileges and Immunities objection to a statute that discriminates against non-domiciliaries would apply only insofar as the statute discriminates against citizens of other U.S. States. ${ }^{128}$ The Due Process objections, on the other hand, would apply equally to international cases. A statute with a geographic scope limitation construed as establishing a different substantive rule for non-domiciliaries would probably violate not only the Privileges and Immunities Clause but also the Due Process Clause, for the reasons discussed above in connection with statutes whose scope is limited to conduct occurring within the state. Facially, it would establish a rule for nondomiciliaries solely on the basis of a lack of connection to the regulating state. As applied, it would establish a rule for non-domiciliaries different from the rule that applies to domiciliaries in cases in which the non-domiciliary fortuitously has sufficient other connections to the state to permit the state to make its law applicable. ${ }^{129}$ If the Due Process objections to this hypothetical statute prevail, they would apply in international as well as interstate cases. In addition, a state law that affirmatively establishes a different substantive rule for non-domiciliaries than for domiciliaries would, in an international case, likely violate treaties of friendship, commerce, and navigation, which typically include a national treatment provision. ${ }^{130}$

\footnotetext{
127 See Arthur Taylor von Mehren, Special Substantive Rules for Multistate Problems: Their Role and Significance in Contemporary Choice of Law Methodology, 88 HARV. L. REV. 347 (1974). In encouraging development of special rules for multistate problems, Professor von Mehren cautioned that "the principle of equality requires that a legal order not distinguish between the treatment of localized and multistate situations or transactions unless the circumstances are such as clearly to justify departing from the norm represented by domestic-law solutions." Id. at 357.

128 U.S. CONST. art. IV, $\$ 2$, cl. 1, "the Citizens of each State shall be entitled to all Privileges and Immunities of Citizens in the several States."

${ }^{129}$ Not all laws that draw distinctions among types of affiliations a person might have with the enacting state are unconstitutional. For example, a law restricting voting to persons who are citizens of the state would be valid. It is well established that political rights can be restricted to citizens. See International Covenant on Civil and Political Rights, art. 25, Dec. 19 1966, 999 U.N.T.S. 171 (entered into force Mar. 23, 1976). More broadly, statutes conferring public benefits can generally be restricted to persons having some affiliation with the enacting state, although the U.S. Constitution imposes some limits here as well. See, e.g., Shapiro v. Thompson, 394 U.S. 618, 638 (1969) (holding that the fundamental right to travel and the equal protection clause forbid a state from reserving welfare benefits only for persons that have resided in the state for at least a year).

130 See Herman Jr. Walker, Modern Treaties of Friendship, Commence and Navigation, 42 MinN. L. REV. 805, 811 (1958). "National treatment" typically means "treatment accorded within the territories of a Party upon terms no less favorable than the treatment accorded therein, in like situations, to
} 
The foregoing constitutional objections affect only geographic scope limitations in statutes enacted by U.S. states, if construed as the Third Restatement would apparently construe them. If geographic scope limitations in statutes enacted by another country were construed as establishing a different substantive rule for nonresidents or non-domiciliaries, their validity could be questioned as violations of national treatment provisions in FCN treaties and perhaps some regional trading arrangements. ${ }^{131}$ In addition, provisions that purport to establish a rule for nonnationals acting outside the state's territory could raise questions under general principles of international law regarding prescriptive jurisdiction, as such principles require a state to have certain specified connections to the enacting state. ${ }^{132}$ Finally, the courts of another state confronted with a law that discriminates so blatantly against its own domiciliaries could legitimately decline to apply such provisions because they are contrary to their public policy.

If the geographic scope limitation were based on the legislature's deference to the law of the state of domicile, it would not be vulnerable to these objections. But a geographic scope provision based on deference to other states does not establish a different substantive rule for cases beyond the statute's designated scope. The enacting state has no law at all for cases beyond the statute's scope. The geographic scope limitation merely reflects the legislature's view that such cases should be governed by the law of a different state. For this reason, they are best understood as choice-of-law provisions.

In sum, a geographic scope provision specifying that a statute extends only to persons or conduct having specified connections to the enacting state is best understood as a choice-of-law rule. If understood to relegate persons or conduct lacking the specified connection to the enacting state to a different rule of the same state-be it the common-law rule that the legislature has found inappropriate for cases with the specified link to the enacted state, or simply "non-regulation"- the resulting legal regime would in most cases be unconstitutional. If the geographic scope limitation were understood as merely expressing the legislature's view that cases beyond the statute's scope should be governed by the law of a different state, the

nationals, companies, products, vessels or other objects, as the case may be, of such Party." Korea FCN Treaty, 1956, T.I.A.S. No. 3947, art. XXII, Para. 1.

131 See, e.g., Chile-European Community Association Agreement, art. 77, Nov. 18, 2002; Decision No 2/2001 of the EU-Mexico Joint Council of 27 February 2001 implementing Articles 6, 9, 12(2)(b) and 50 of the Economic Partnership, Political Coordination and Cooperation Agreement (Article 6. National Treatment).

132 See supra TAN 57-61. 
restriction would be unexceptional. Some statutes distinguishing among the types of affiliations a person might have with the enacting state might be valid (citizen versus non-citizen domiciliaries, for example), as might a statute establishing a special rule for multi-state cases that address legitimate differences between such cases and purely local cases. But a statute specifying that it extends to persons or conduct having specified links to the enacting state without specifying a rule for cases beyond the statute's specified scope should not be interpreted to relegate excluded cases to a different law of the same state. If the legislature did have such an intent, the courts of other states would be within their rights to decline to give effect to it either because it is unconstitutional or simply because it reflects protectionism or hostility and is thus undeserving of respect.

\section{The Obligation to Give Full Faith and Credit to Sister States' GEOGRAPHIC SCOPE LIMITATIONS}

The Constitution provides that "Full Faith and Credit shall be given in each State to the public Acts, records, and judicial Proceedings of every other State."133 This clause imposes on U.S. states strict obligations to recognize and enforce the judicial judgments of sister states, but comparatively weak obligations regarding the application of sister states' laws. ${ }^{134}$ If a state has sufficient contacts with a case to permit it to apply its own law consistent with the Due Process Clause, it is not required under the Full Faith and Credit Clause to apply another state's law to the case. ${ }^{135}$ If it lacks sufficient contacts to apply its own law, it may be required under the Full Faith and Credit Clause to apply the law of a particular sister state. In such cases, the clause is violated if the court misconstrues its sister state's law and its misconstruction "contradicts law of that other State that is clearly established and that has been brought to the court's attention." "The Third Restatement maintains that "[a] State court applying another State's statute to a set of facts outside its specified scope would violate the Full Faith and Credit Clause, if the scope restriction is clear and brought to the court's attention."137

If this argument is based on an understanding of geographic scope limitations as reflecting the legislature's intent to create a different rule of that state for cases beyond a statute's specified scope, the argument under the Full Faith and Credit Clause fails for the reasons discussed in Part IV. The claim that this is what a legislature means when it enacts a geographic scope limitation is highly implausible, and, in any

133 U.S. CONST., art. IV, $\int 1$.

134 See Baker v. General Motors Corp., 522 U.S. 222, 232-33 (1998).

135 See Allstate Ins. Co. v. Hague, 449 U.S. 302, 313 (1981).

136 Sun Oil Co. v. Wortman, 486 U.S. 717, 730-31 (1988).

${ }^{137} \mathrm{Id}$. $\$ 5.02$ comment b on subsection (1). 
event, interpreting the statute that way would likely violate the Privileges and Immunities Clause and the Due Process Clause (not to mention possibly violating FCN treaties). A state cannot be guilty of violating the Full Faith and Credit Clause for failing to respect a statutory provision that is itself unconstitutional.

Indeed, the Supreme Court's recent decision in Franchise Tax Board of California v. Hyatt ${ }^{138}$ establishes that a statute of the kind discussed in Part IV would violate the Full Faith and Credit Clause itself. In Hyatt, a Nevada resident sued California tax authorities in the Nevada courts, alleging several intentional torts. ${ }^{139}$ California law gave tax authorities absolute immunity from these intentional tort claims. Nevada law permitted these claims but subjected them to a $\$ 50,000$ damage cap. In Hyatt $I$, the Supreme Court upheld the Nevada court's decision not to apply California's absolute immunity rule. ${ }^{140}$

On remand, the Nevada courts declined to give California's tax authorities the benefit of the $\$ 50,000$ damage cap provided by Nevada law. This damage cap, the Nevada court held, was applicable only to Nevada tax authorities. This time, the U.S. Supreme Court held that Nevada had violated the Full Faith and Credit Clause. In the terms we have been using, the Nevada court construed the Nevada statute imposing a $\$ 50,000$ cap on damages as being subject to a geographic scope limitation-it applied only to the tax authorities of the state of Nevada. Moreover, it construed this geographic scope limitation the way the Third Restatement understands geographic scope limitations - that is, as establishing a different substantive rule of Nevada applicable to out-of-state taxing authorities (i.e., a rule allowing recovery without a damage cap). Establishing a special rule for out-of-state cases, the Court concluded, violates the Full Faith and Credit Clause:

Nevada has not applied the principles of Nevada law ordinarily applicable to suits against Nevada's own agencies. Rather, it has applied a special rule of law applicable only in lawsuits against its sister States, such as California. With respect to damages awards greater than $\$ 50,000$, the ordinary principles of Nevada law do not "conflic[t]" with California law, for both laws would grant immunity. . . . Similarly, in respect to such amounts, the "polic[ies]" underlying California law and Nevada's usual approach are not "opposed"; they are consistent .... But that is not so

\footnotetext{
138136 S. Ct. 1277 (2016) (Hyatt II).

139 The suit was brought before the Court held (in a later appeal in Hyatt itself) that state instrumentalities are constitutionally entitled to sovereign immunity from suit in the courts of sister states. See Franchise Tax Bd. California v. Hyatt, 139 S. Ct. 1485 (2019) (Hyatt III) (overruling Nevada v. Hall, 440 U.S. 410 (1979)). The sovereign immunity holding of Hyatt III does not call into question the Full Faith and Credit holdings of Hyatt I and II.

140538 U.S. 488 (2003) (Hyatt I).
} 
in respect to Nevada's special rule. That rule, allowing damages awards greater than $\$ 50,000$, is not only "opposed" to California law; it is also inconsistent with the general principles of Nevada immunity law...

A constitutional rule that would permit this kind of discriminatory hostility is likely to cause chaotic interference by some States into the internal, legislative affairs of others. ${ }^{141}$

Because Nevada's special rule for out-of-state tax authorities "reflects a constitutionally impermissible 'policy of hostility to the public Acts' of a sister State, ${ }^{\prime 142}$ the Court concluded that it violated the Full Faith and Credit Clause.

The Court thus held that a state's courts may apply its own local law, disregarding geographic scope limitations. The Court called these the "ordinary principles of Nevada law," by which it meant the principles that Nevada applies to local cases. It may also apply its sister's state's local law. But it may not fashion a special rule to cover only out-of-state cases. The Court did not completely rule out the possibility that a state could provide "sufficient policy considerations" for such a special rule that did not reflect disparagement or hostility towards sister states, ${ }^{143}$ but it gave no clue as to what such policy considerations would look like. Presumably, a special rule treating out-of-state cases more favorably than in-state cases, or a special rule for multi-state cases of the sort Professor Von Mehren proposed, would pass muster. ${ }^{144}$ But, in light of the above analysis, it is difficult to conceive of valid policy reasons that would justify a statute that establishes a different substantive law of that state solely for out-of-state cases that treats out-of-state persons or conduct less favorably. Indeed, geographic scope provisions, so construed, would appear to violate other clauses of the Constitution. ${ }^{145}$

If we reject the idea that a geographic scope limitation establishes a different substantive rule of the state for excluded cases, and accept that a state has no law for cases beyond the statute's specified scope, does a court of State B violate the Full Faith and Credit Clause if it applies the substantive law of State A to cases beyond the specified scope of the statute? The Supreme Court's Full Faith and Credit decisions suggest a negative answer but do not definitively resolve the question. For example, the Court has held that the Full Faith and Credit Clause is not violated when a court entertains a cause of action created by the law of a sister state but disregards a provision in the statute purporting to limit adjudication of such actions to the courts

141136 S. Ct. at 1282.

${ }^{142} I d$.

$143 \mathrm{Id}$.

${ }^{144}$ For examples, see supra TAN 126-127.

145 See supra Part IV. 
of that state. ${ }^{146}$ Provisions limiting the adjudication of a cause of action to the courts of the enacting state have been called "localizing rules," have used to refer to geographic scope limitations as well. ${ }^{148}$ But the former provisions serve to reserve judicial jurisdiction to the enacting state's courts, rather than limit the geographic scope of the substantive law. Whether the Court's reasoning in these cases extends to questions of geographic scope is debatable. ${ }^{149}$

More recently, the Court in Sun Oil Co. v. Wortman stated that "[i]t cannot possibly be a violation of the Full Faith and Credit Clause for a State to decline to apply another State's law in a case where that other State itself does not consider it applicable." ${ }^{\prime 150}$ But our question is the converse one: whether it violates the Full Faith and Credit Clause for a state to apply the substantive law of a sister state even though the sister state does not consider it applicable. Hyatt comes closer to addressing the question. The Court's exclusive focus on the obligation of states to respect their sister states' substantive policies suggests that the Full Faith and Credit Clause does not require respect for a sister state's procedural or choice-of-law policies, as does its suggestion that Nevada was free to apply its own damage cap rather than California's absolute immunity rule, despite the damage cap's implicit geographic scope limitation. But Hyatt does not expressly address a state court's obligation to respect a sister state's geographic scope limitations.

Despite the lack of direct precedents, rejection of the Third Restatement's claim regarding the Full Faith and Credit Clause is required by broader considerations. First, if a geographic scope limitation is based on the legislature's deference to the legislative authority of other states, then the only message such a provision is meant to convey is that the legislature regards case beyond the statute's specified scope to be governed by the law of another state. To require a state to respect a sister state's statutory provision telling us that another state's law should be applied to the case is to require courts to engage in renvoi. As discussed in Part VII, there may be a proper role for renvoi in choice of law, especially in cases involving geographic scope limitations. But the traditionally accepted rule has long been that renvoi is prohibited except in limited categories of cases. Indeed, both the Second and Third

146 Crider v. Zurich Ins. Co., 380 U.S. 39 (1965); Tennessee Coal, Iron \& (and) R.R. Co. v. George, 233 U.S. 354 (1914); Atchison, Topeka and Santa Fe Ry Co. v. Sowers, 213 U.S. 55 (1909).

147 See Sedler, supra note 2, at 6162.

148 See, e.g., Kelly, supra note 36; Kinsch, supra note 94.

149 The Court in George held that a state could not create a transitory cause of action yet limit its enforcement to its own courts, but it also said that " $[\mathrm{t}]$ he courts of the sister state would be bound to give full faith and credit to all those substantial provisions of the statute which inhere in the cause of action or which name conditions on which the right to sue depend." 233 U.S. at 360. This dictum is unproblematical insofar as the Court was referring to internal scope limitations. It is not clear whether the Court meant to refer to geographic scope limitations as well. 150486 U.S. at 730, n.3. 
Restatements frown on renvoi for the vast majority of cases. It would be odd to conclude that an approach that has long been disfavored is actually constitutionally required. ${ }^{151}$

Second, if a geographic scope limitation does reflect the legislature's deference to the legislative authority of other states, then it does not reflect the legislature's view that the substantive law it has enacted is inappropriate for cases beyond the statute's specified scope. It does not reflect the legislature's preference that the substantive rules not be applied to cases beyond its specified scope. If the sister state to which the legislature deferred declines the deference and concludes that the enacting state's substantive rule should be applied notwithstanding the geographic scope limitation, the sister state is not disrespecting the preferences of the enacting state's legislature. Indeed, one might say that the sister state is giving the enacting state's substantive law more faith and credit than the enacting state's legislature has asked for. If this analysis is correct, then the Full Faith and Credit requires states to respect only the local laws of sister states (understood as the Second Restatement defines it), not provisions specifying the geographic scope of such laws.

Finally, if we recognize that a state that has enacted a statute but limited its scope to cases having specified links to the state does not have a law for cases lacking the specified links to the state, it is impossible to maintain that a court fails to give due faith and credit to the law of its sister state by applying that law's substantive provisions to cases beyond its specified geographic scope. If State B courts apply the substantive provisions of State A law to cases beyond the statute's specified scope, they cannot have failed to give full faith and credit to State A law because, for cases beyond the statute's specified scope, there is no State A law for State B courts to disrespect. ${ }^{152}$ The analysis would be different if a sister state has applied a State A statute to cases beyond the scope of an internal scope limitation. In such cases, State A does have a different law to govern cases beyond the statute's specified scope. But, if State A has no law to govern such cases, a court cannot have failed to give proper faith and credit to a sister state's law.

At bottom, it would appear that the Third Restatement's position does not rest on an obligation to respect a sister state's laws, but rather on the notion that a

151 See Wortman, 486 U.S. at 728-29 ("[L]ong established and still subsisting choice of law practices that come to be thought, by modern scholars, unwise, do not thereby become unconstitutional.") (plurality opinion).

152 Recall that we are assuming here that a statute with a geographic scope limitation does not prescribe non-regulation for cases beyond the statute's specified scope. If it did prescribe nonregulation, it would be unconstitutional for the reasons given in Hyatt and those discussed in Part IV. 
court cannot decide a case in the absence of law. ${ }^{153}$ If a state that has enacted a statute with a geographic scope limitation has no law at all for cases beyond the statute's geographic scope, a court that applies the substantive provisions of the statute to cases beyond its scope would appear to be deciding a case pursuant to no law at all. But "[r] ights that can be enforced in court do not exist in the abstract. Courts only enforce rights that are conferred by positive law. ${ }^{154}$ If one accepts this premise about the obligations of courts, does my argument that states are free to base their decisions on a substantive rule that, by its terms, does not extend to the case at hand mean that what we have been calling geographic scope limitations do not in fact operate as geographic scope limitations? That is the question addressed in the next Part.

\section{Are “GeOgraphic Scope Limitations” Geographic Scope Limitations?}

My analysis in the previous Parts of this Article appears to lead to a startling conclusion: statutory provisions designating the geographic scope of statutes should not be read to limit the geographic scope of statutes. If these provisions do indeed limit the geographic scope of the statute, as they purport to do, then it seems to follow that a court applying the statute's substantive provisions beyond its specified scope commits an error (even if doing so would not violate the Full Faith and Credit Clause). If State A has a substantive law but that law only purports to reach persons or certain conduct having specified connections to the enacting state, then, if State B applies the substantive rule to other persons or conduct, it would appear to be applying a rule that does not reach the case. It would appear to be resolving the case on the basis of no law.

On the other hand, our analysis of the purpose of the limitation showed that a court applying the substantive provisions of the statute beyond its specified scope would not be contravening the preferences of the enacting legislature. Other states should be free to decline the deference the enacting legislature has shown towards it. But, if the substantive rule can be applied by the courts of other states despite the geographic scope provision, is the provision really limiting the substantive scope of the substantive law, as it purports to do? If the geographic scope limitation does limit the reach of the law, are the courts of other states that apply that law to a case beyond the statute's reach violating their obligation to decide cases according to law?

153 This principle might itself have constitutional status. If so, its home would probably be the Due Process Clause.

154 See Kramer, supra note 117, at 1052. The views of the Third Restatement's reporter on the questions addressed in this Article are deeply influenced by this article. Roosevelt Letter, supra note 53 ("The main source for this perspective, I would say, is Larry Kramer, and in particular his article The Myth of the Unprovided-for Case, 75 Va. L. Rev. 1045 (1989).”). 
One possible way out of this conundrum would be to interpret the scope limitation as specifying the statute's minimum, rather than maximum, scope. ${ }^{155}$ This solution will be consistent with the statutory language of many, perhaps most, geographic scope limitations. A statute that says that it extends to injuries that occur within the state does not say that it does not to extend to injuries occurring outside the state. Maxims of interpretation (e.g., expressio unius est exclusion alterius) could lead a court to interpret the provision as setting forth the statute's maximum scope, but, for the reasons given in the foregoing Parts of this article, courts employing a purposive analysis would be justified in rejecting such an interpretation.

If a statute is amenable to such a construction, the courts of the enacting state could justifiably interpret the limitation as specifying the statute's minimum scope. So understood, the provision reflects the legislature's view that the state's interest in applying the substantive rule is at its apex in the specified circumstances, while at the same time acknowledging that in other cases it may be more appropriate to apply the law of another state. This construction leaves it open to the enacting state's courts to apply the substantive rule of the statute beyond the statute's specified scope if, for example, the other states connected to the dispute have similarly deferred to other interested states either through their geographic scope limitations or through their choice-of-law rules. If the courts of State A have construed State A's geographic scope limitation in this way, then the courts of States B and C would be equally warranted in applying the substantive provisions of the State A statute to cases not within the statute's specified geographic scope, at least in the circumstances State A's courts would do so. This solution to our conundrum would likely take care of the vast majority of cases. ${ }^{156}$

But what if the State A legislature has clearly phrased the geographic scope limitation as a maximum limit? In the face of clear statutory language, the courts of State A would likely feel constrained to interpret the limitation as expressing the maximum scope of the statute. This is true even if we understand such a provision as a choice-of-law rule. A state's legislature has the power to legislate choice-of-law rules

155 This approach has been favored by David F. CAvers, ChOICE-OF-LAw Process, 245-46 (1965). See also D. St. L. Kelly, Localising Rules and Differing Approaches to the Choice of Law Process, 18 INT’L \& COMP. L.Q. 249, 273-74 (1969). See also KELLY, supra note 36, at 31 (“Express localizing rules [Kelly's term for geographic scope limitations] are normally concerned with the minimum application sought to be ensured for certain decisional [i.e., substantive] rules by the legislator, rather than with setting the outer limits of the relevance of those rules. Localizing rules of this type are directive but not exclusive. In other words, while directing the application of the decisional rules which they qualify to a minimum set of circumstances they do not exclude the possibility of further application of those rules in appropriate circumstances...." (emphasis in original.))

156 See KELLY, supra note 155, at 31 ([Although] it is possible that the localizing rules of each of the respective legal systems may appear, on interpretation, to be exclusive of further application[,] ... the likelihood in practice of so fatal a conjunction of circumstances is a remote one indeed.) 
for the courts of the state. The Second and Third Restatements both provide that the courts of a state will follow a choice-of-law directive of its own legislature. ${ }^{157}$ Even if we accept that the legislature enacted the particular scope limitation to identify the types of cases it regarded as most important, without meaning to suggest that it would prefer that its substantive rule not be applied to cases outside its specified scope, the geographic scope limitation may reflect the legislature's additional purpose of simplifying the courts' burden by providing an easy-to-administer choice-of-law rule. Thus, there are legitimate reasons why the courts of the enacting state would treat a clearly phrased maximum scope limitation as binding, even if they regarded the provision as a choice-of-law rule.

Moreover, in some cases, interpreting the statute to extend to cases beyond the its clearly expressed maximum scope may raise constitutional problems. This would be the case if the statute imposes criminal penalties, or is otherwise "penal" in nature. ${ }^{158}$ But states generally do not enforce the penal laws of other states, so statutes of this nature are not likely to pose the problem under discussion here. ${ }^{159}$ More generally, though, there may be constitutional problems, or at least fairness concerns, in applying a statute beyond its clearly expressed maximum scope where private parties may have reasonably relied on the statute's limited geographic reach in structuring their conduct. These fairness concerns will not be implicated in all cases. Some legal rules are not of the type that persons rely on in structuring their primary conduct. ${ }^{160}$ Even if private parties do rely on such limitations in structuring their conduct, the reliance may be thought to be unreasonable in certain cases. ${ }^{161}$ In cases that do raise fairness or reliance

157 See Second Restatement, $\int 6(1)$; Third Restatement (Council Draft No. 1), id., Council Draft No.1, \5.02(1) (Nov. 11, 2016).

158 See, e.g., Chicago v. Morales, 527 U.S. 41, 51 (1998) (invalidating a loitering ordinance for being unconstitutionally vague); Papachristou v. Jacksonville, 405 U.S. 156, 162 (1972) (striking down a vagrancy ordinance because its language failed to "give a person of ordinary intelligence fair notice that his contemplated conduct is forbidden"); Coates v. Cincinnati, 402 U.S. 611, 612-13 (1971) (holding that a city ordinance banning conduct "annoying to persons passing by" was unconstitutionally vague).

159 See generally BRILMAYER, supra note 62, at 156-63.

160 See Second Restatement, $\$ 6$ comment g ("There are occasions, particularly in the area of negligence, when the parties act without giving thought to the legal consequences of their conduct or to the law that may be applied.”). See also Schultz v. Boy Scouts of Am., Inc., 65 N.Y.2d 189, 198 (1985).

161 Take, for example, a case in which all of the relevant states have the same substantive rule, but each has a different scope limitation, and the case before the court falls between the cracks of these scope limitations. Under such circumstances, the courts of State A might be justified in reading an exception into the statute's scope limitation, making the limitation inapplicable (and thus the substantive provisions applicable), to cases in which all other relevant states have the same substantive rule. Private parties are unlikely to have structured their conduct in reliance on their conduct falling between the cracks of each state's scope limitation, and, if they did, their reliance 
concerns, State B can and should structure its choice-of-law rules to take account of them, and in some cases they may be constitutionally required to do so. ${ }^{162}$

But what about cases that do not raise fairness or reliance concerns? In such cases, should the courts of State B feel any compunction about applying State A's substantive law to the case beyond the statute's clearly expressed maximum geographic scope limitation if, under State B's choice-of-law rules, the law of State A applies to the case? State B could justifiably treat the geographic scope limitation as an invitation to apply its own substantive law, or that of a third state, to the matter. ${ }^{163}$ Nevertheless, State B may prefer to stick to its own choice-of-law rules. It too may prefer a simpler choiceof-law rule in order to lessen the burden on its own courts and to give litigants a greater measure of certainty and predictability, and it may be confident that its own choiceof-law rules accomplish those tasks more effectively. If geographic scope limitations are understood as choice-of-law rules (as argued here), then the Second Restatement, and even the Third Restatement (in its black letter) instruct the State B courts to apply State A substantive law, disregarding its geographic scope limitations. ${ }^{164}$

But, if the substantive provisions of the State A statute can be applied by State B courts notwithstanding the geographic scope limitation, is the geographic scope limitation actually functioning as a limit on the geographic reach of the statute? If the statute, because of the geographic scope limitation, does not reach the case, then is State B's application of State A's statute beyond its specified scope a violation of its obligation to decide the case according to law?

on this might be regarded as unreasonable. See generally Vázquez, Choice of Law Step Zero, supra note 97.

${ }^{162}$ Cf., e.g., Second Restatement $\ 6$ (2)(d) (listing "the protection of justified expectations" as one of the "factors relevant to the choice of the applicable rule of law" when the forum does not have a statutory directive on choice of law). See generally Lea Brilmayer, Rights, Fairness and Choice of Law, 98 YALE L. J. 1277 (1989).

163 The State B courts would not be contravening the intent of State A's legislature of reducing the burden on the courts, as presumably State A's legislature only meant to simplify the task of State A's courts.

164 See supra TANs 14-30. See also David F. Cavers, An Approach to Some Persistent Conceptual Problems, 131 ReCueIL Des Cours 122, 134 (1970) ("Even to those who believe that the other state's choice-of-law rules may be ignored, the disregard of the localizing limitation on a substantive rule seems an impermissible distortion of that law which it may fairly, if metaphorically, be said does not "want" to be applied. But must its wishes be respected? The matter, it must be remembered, is not one that is exclusively the concern of the state whose statute is in question. It is the forum that has the responsibility of resolving the case before it. If it sees the application of State X's substantive rule as achieving fairness to the parties as well as a sensible allocation of rule-making responsibility among states, why should the forum be restrained from exercising its authority by the fact that the contrary view of State $\mathrm{X}$ is embodied in a statutory limitation rather than in a choice-of-law rule?"). 
The answer to this question depends on how choice-of-law rules are conceptualized. As noted, there is a school of thought, long prominent in the United States, that understands the function of all choice-of-law rules to be the implicit determination of the geographic scope of forum law. ${ }^{165}$ Under this view, a state's decision that the case before it is governed by the law of another state is an implicit determination that forum law does not extend to the case. Yet, at the same time, the traditional rule in the United States has been that, when the forum's choice of law rules direct application of another state's law, they call for application of that state's substantive law whether or not that state's courts would apply that law. The coexistence of an understanding of choice-of-law rules as specifying the geographic scope of forum law and the proposition that a state's choice-of-law rules direct application of another state's law regardless of whether that law would be applicable under the other state's choice of law rules tells us that there is no constitutional problem when courts apply a sister state's law to cases beyond their geographic scope. Yet the question remains: How is this consistent with a court's obligation to decide cases according to law?

One possible answer is that choice-of-law rules do not in fact operate to limit the geographic scope of a state's laws. Instead, choice-of-law rules might be understood as merely instructing the forum's courts not to apply the forum's concededly applicable law to cases lacking certain connections to the forum state. ${ }^{166}$ So understood, a state's choice-of-law rules function as a sort of procedural rule, instructing the forum courts not to apply forum law to certain disputes to which they concededly extend, but not purporting to bind the courts of other states. Among the problems with this view, however, is that it would regard each state's substantive laws as potentially applicable world-wide. Even though the enacting state's courts would not apply the substantive law to cases lacking the requisite connection to the forum, the law remains in principle applicable to "a hand on a Chinese junk, never outside Chinese waters." 167 With respect to express maximum geographic scope limitations, there is the additional problem that such an understanding of the provision is inconsistent with the way the statutes are written, as well as how presumptions against extraterritoriality are understood to operate. ${ }^{168}$

\footnotetext{
165 See generally Vázquez, supra note 13.

166 This is how Professor Kramer appeared to understand some, but not all, choice-of-law rules in Larry Kramer, The Return of the Renvoi, 66 N.Y.U.L. Rev. 979, 1034 (1991). For my critique of this argument, see Vázquez, supra note 13.

${ }^{167}$ Lauritzen v. Larsen, 345 U.S. 571, 577 (1953).

${ }^{168}$ Even in the face of express statutory language, this reconceptualization of geographic scope provisions could be defended on the ground that, (a) notwithstanding their language, such provisions have long been regarded as unilateral choice-of-law provisions, and (b) it has long been understood that the courts of one state are not bound by the choice-of-law provisions of other states. (Indeed, they have generally been instructed not to apply them). But the alternative
} 
A more satisfying answer emerges if we shift out focus to how State B's choiceof-law rules operate. When a court adjudicates a case pursuant to a sister state's substantive law that does not extend to the case of its own force, the court is deciding the case according to law: it is deciding the case pursuant to the forum's choice-oflaw rules, which are a part of its law. The forum's choice-of-law rules might instruct the court to apply a sister state's substantive law only when those laws would be applicable to the dispute of their own force. (This is what the forum's choice-of-law rules instruct if they authorize renvoi.) But, if the forum's choice-of-law rules reject renvoi, as most states have traditionally done (and as both restatements do), they instruct the forum's courts to apply a sister state's substantive law even if those laws do not extend to the case of their own force. ${ }^{169}$ Doing so would be consistent with the court's obligation to decide cases according to law if one conceives of the forum's choice-of-law rules as incorporating the substantive provisions of the chosen state's law as the forum's law for the purpose of deciding cases such as the one before it.

There is, indeed, a long history of conceiving of choice-of-law rules this way. According to the "local law" theory of choice-of-law, a court always applies forum law in deciding cases. When it resolves a case by applying a foreign substantive rule, it is not applying the foreign rule as such. Rather, it is formulating a domestic rule of law whose content is "as nearly homologous" as possible to that of the state selected by the forum's choice-of-law rules. ${ }^{170}$ The local law theory has a hoary pedigree. The standard citation for it is to an opinion by Judge Learned Hand, Guinness v. Miller. ${ }^{171}$ Its most famous scholarly proponent was Walter Wheeler Cook, ${ }^{172}$ who is widely thought to have bested Joseph Beale in his critique of Beale's work as reporter of the First Restatement of Conflict of Laws. ${ }^{173}$

It is true that the "local law" theory has few contemporary proponents. Our discussion suggests that there is more to this theory than contemporary scholars recognize. In any event, to solve our conundrum, we need not accept every aspect of

conceptualization offered below does less violence to statutory text and the way geographic scope limitations have long been understood.

169 This would be true, at least, if the choice-of-law rules of the selected state are understood, by that state, as specifying the geographic scope of its laws (as they have traditionally been understood, at least in the United States).

170 Cavers, supra note 107 , at 824.

171291 Fed. 769 (S.D.N.Y. 1923), aff'd, 299 Fed. 538 (2d Cir. 1924), aff'd sub nom. Hicks v. Guinness, 269 U.S. 71 (1925).

172 See Walter WheEler CoOK, THE LOgiCAL And Legal Foundations of THE CONFLICT OF LAWS (1924).

173 Brainerd Currie wrote that Cook's work had "discredited the [Beale's] vested rights theory as thoroughly as the intellect of one man can ever discredit the intellectual product of another." CURRIE, supra note 93, at 6. 
the old local law theory, nor need we conclude that this is the best way to understand choice-of-law rules. There is no single way to understand such rules. In the absence of a treaty or other binding higher law, choice-of-law rules are a creature of each state's positive law. This means that, within such limits, it is for each state to determine how its conceives of its choice-of-law rules. If a state rejects renvoi, it instructs its courts to apply the substantive law of another state even to cases to which the enacting state would not regard its law applicable. ${ }^{174}$ For such a state, the courts in such cases would be complying with their obligation to decide cases according to law if they understood their choice-of-law rules as incorporating the other state's substantive law as its own for purposes of cases such as the one before it.

One sort of higher law to which U.S. states are bound is the U.S. Constitution, which, as we have seen, allows a state to apply its own law to a case only if it has sufficient contacts to the dispute. ${ }^{175}$ As noted, the limits the Constitution imposes in this regard are rather weak. If the forum has enough contacts to the dispute that it that it may apply its own law, then it may unproblematically apply the substantive law of a sister state qua its own law. There may, however, be cases in which the forum lacks sufficient contacts to apply its own law. It might be argued that the Constitution prevents a wholly disinterested forum from applying the substantive law of a sister state qua the law of the forum, incorporated via the forum's choice-of-law rules. But the long history of treating choice-of-law rules as implicit limits on the geographic scope of forum law, combined with our traditional rejection of renvoi, support the contrary conclusion. If "[l]ong established and still subsisting choice of law practices that come to be thought, by modern scholars, unwise, do not thereby become unconstitutional," ${ }^{176}$ then the better view is that the Constitution prohibits a wholly disinterested forum from applying its own local law but does not prohibit it from incorporating via its choice-of-law rules the substantive law of a state that does have sufficient contacts to the dispute, even if the enacting state would not consider its law applicable. Doing so would not violate the Full Faith and Credit Clause because the state whose law is being applied has no law that extends to the dispute of its own force. And doing so would not violate the Due Process limits on choice of law because the state whose substantive law is being applied does have sufficient contacts with the dispute. Apart from constitutional concerns sounding in fairness to the parties (which will in most cases be addressed in the forum's choice-of-law rules), there should be no constitutional problem with a state regarding its choice-of-law rules as incorporating the substantive law of a state that has sufficient contacts with the dispute.

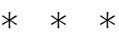

\footnotetext{
174 This is so at least if the other state conceives of its choice-of-law rules as specifying the geographic scope of its laws, as U.S. states have also long done.

175 See Allstate v. Hague, 449 U.S. 302 (1981).

176 Sun Oil Co. v. Wortman, 486 U.S. at 728-29.
} 
In sum, as the enacting state's choice-of-law rule, geographic scope provisions are binding on the courts of the enacting state. However, most of them can and should be construed to specify the statute's minimum rather than maximum scope, permitting the statute's substantive provisions to be applied to cases beyond the statute's specified scope in appropriate circumstances. Moreover, even if the provision is clearly written as specifying the statute's maximum scope, the courts of other states would not be contravening the wishes of the enacting legislature if it applied the statute's substantive provisions of the statute to cases beyond its specified scope. Even if framed as a maximum scope limitation, the limitation is based on deference to the legislative authority of other states, and thus functions as a choice-of-law rule. Applying a sister state's substantive law to cases beyond its specified geographic scope does not violate the Full Faith and Credit Clause or the choice-of-law aspects of the Due Process Clause, although, in some cases, doing so might violate the Due Process Clause by defeating the parties' legitimate reliance interests. Applying a sister state's law to cases beyond the statute's specified geographic scope is consistent with the obligation of courts to decide cases according to law if the forum understands its choice-of-law rules as incorporating the selected state's substantive law as its own for the purposes of adjudicating cases such as the one before it.

\section{APPLICATIONS}

My claim that geographic scope limitations are best regarded as choice-of-law rules has significant implications for the treatment of contractual choice-of-law clauses and for the question of renvoi. I discuss those implications in this Part.

\section{A. Contractual Choice-OF-Law Clauses and Scope-Limited Laws}

Both the Second and Third Restatements give parties broad authority to select the law that shall govern their contractual relationship. Under both the Second and Third Restatement, a choice-of-law clause is valid with respect to issues the parties could have resolved through an explicit agreement in their contract. ${ }^{177}$ For other issues, the choice-of-law clause is valid under both restatements if the chosen state has a substantial relationship to the parties or there is another reasonable basis for the parties' choice and the application of the chosen law does not contravene a fundamental policy of the state whose law would apply in the absence of the clause. ${ }^{178}$ If the clause is valid, a further question is whether the selected state's law was intended to govern only issues of contract law or all issues arising from the contractual relationship. ${ }^{179}$ If the clause is valid and covers statutory issues, the court must determine what to do when the

177 Second Restatement \187(1); Third Restatement, supra note 20, \8.02(1).

178 Second Restatement $\$ 187(2)$; Third Restatement, supra note $20, \$ 8.02(2)-(3)$.

179 This issue is addressed in the Third Restatement, supra note 20, $\int 8.03(2)(a)-(b)$. 
state whose law has been selected by the parties includes a statute that includes a geographic scope limitation, and the case before the court is beyond the statute's specified geographic scope.

Both restatements recognize that this question is ultimately one of determining the parties' intent. If the parties speak clearly enough, they may include or exclude scope-limited statutes. But the restatements have different rules for interpreting contractual choice-of-law clauses that do not expressly address the question of scopelimited statutes. The Second Restatement establishes a presumption that the parties intended to select the "local law" of the state, ${ }^{180}$ by which the Second Restatement means the substantive law of that state, disregarding any geographic scope limitations. ${ }^{181}$ The Third Restatement similarly establishes a presumption that the clause selects the "internal law" of the selected state, but it defines "internal law" as the state's substantive law subject to any geographic scope limitations. ${ }^{182}$ Thus, the Third Restatement does not establish a presumption that the parties selected the substantive law of the selected state exclusive of its geographic scope limitations.

As noted, the Third Restatement appears to understand scope-limited statutes as prescribing "non-regulation" for cases beyond the statute's specified geographic scope. ${ }^{183}$ If that is what geographic scope limitations do, then there should be no need for special instructions for interpreting contractual choice-of-law clauses in the face of scope-limited laws. If the selected state does have a rule for cases beyond the scope of the scope-limited statute, it is presumably those rules that the parties selected in their choice-of-law clause. But the Third Restatement's understanding of a geographic scope limitation as prescribing non-regulation for cases beyond the statute's specified scope produces a number of problems and anomalies in the context of choice-of-law clauses, and the Third Restatement seeks to address these issues in a section specifically addressing the interpretation and validity of such clauses when the selected state has a statute that contains such a limitation (section 8.04). The section begins by instructing the courts that, in determining whether a choice-of-law clause incorporates the substance of a scope-limited law even for cases beyond its specified scope, they must seek to ascertain the parties' likely intent. ${ }^{184}$ The comments then go on to offer insights into circumstances in which the parties' choice of a scope-limited law was

\footnotetext{
180 Second Restatement, $\int 187(3)$.

181 See supra Part I.

${ }^{182} \mathrm{Id}$.

183 See supra TAN 103. But cf. supra note 108 (noting ambiguities in the Third Restatement's position).

184 See Third Restatement, supra note 20, \8.04(1).
} 
likely to have been intended to select "non-regulation," and guidance as to when such a choice would be valid. ${ }^{185}$

Because it is not entirely clear how the Third Restatement would resolve all of the permutations of the hypothetical cases it discusses, it is difficult to say whether the complex combination of interpretive guidance it gives and the conclusions it reaches about the validity of choice-of-law clauses in the face of scope-limited laws successfully avoid the numerous anomalous results that its understanding of geographic scope limitations could produce. ${ }^{186}$ There is no doubt, however, that the interpretive presumption established by the Second Restatement is far easier to apply than the Third Restatement's provisions on the subject. The Second Restatement's presumption is thus more consistent with a key purpose of choice-of-law clauses: obviating complex choice-of-law questions. This is the reason given by both restatements for presuming that a choice-of-law clause does not select the chosen state's whole law. As the Second Restatement notes, to interpret the clause otherwise "would introduce the uncertainties of choice of law into the proceedings and would serve to defeat the basic objectives, namely those of certainty and predictability, which

185 The comments tell us that the parties are likely to have intended to incorporate the substance of a scope-limited statute if they specifically mentioned the statute in the contract. See id. $\$ 8.04$ comment b \& Illustration 6, comment d \& Illustration 9, comment e. Other comments indicate that the choice of a scope-limited statute will sometimes be invalid if the choice of "non-regulation" would conflict with a mandatory provision of the state whose law would otherwise apply. See id. $\$$ 8.04 comment $\mathrm{d} \&$ Illustration 9. If the choice of non-regulation would not conflict with a mandatory provision of another state's law (that is, if the substantive provisions of the other state's law are waivable), the choice of the law of a state with a scope-limited statute would be valid. See $i d$. But, in some such cases, the Third Restatement suggests that the parties are likely to have intended to incorporate the substance of a scope-limited statute into their contract, even if they did not mention the law in the clause, if (a) the contract also expressly waives claims under other states' laws, and (b) giving effect to the scope limitation would leave the parties without the protection of any state's law on the issue. See id. comment b Illustration 7.

${ }^{186}$ For example, Illustration 9 tells us that, if a choice-of-law clause selects the law of State Y and State Y has a Franchise Act that extends only to franchises operating in State Y, the clause "is effective" at excluding the law of State $\mathrm{X}$ if the franchise operates in State $\mathrm{X}$ and the State $\mathrm{X}$ Franchise Act is waivable. This means that, even if both Franchise Acts probibit termination without cause, the selection of State Y law "is effective" and, because the law of State Y for cases beyond the Franchise Act's scope is non-regulation, termination without cause is permitted. The choice-oflaw clause thus produces the anomalous result of making applicable a rule of law that is contrary to the rule that both states would apply to purely local cases. (As to whether this is likely to have been the parties' intent, see infra notes 199 and 201.) Illustration 7, however, suggests that it would be reasonable in certain circumstances to assume that the parties intended to incorporate the substance of a scope-limited statute, even when it would exclude application of the waivable law of another state, if doing so would leave the parties without any rights. See supra TAN 185. Whether the interpretive guidance in Illustration 7 would apply to the facts of Illustration 9 is unclear. 
the choice of law provision was designed to achieve." ${ }^{187}$ Requiring the court to determine whether a given statute applies to the contractual relation of its own force, as the Third Restatement does, re-introduces potentially complex questions the parties likely wished to avoid. There may be substantial questions in any given case about whether the case falls within the scope of a statutory geographic scope limitation. ${ }^{188}$ Even when the statute does not include a geographic scope limitation, some state courts have read such scope limitations into a statute, raising additional interpretive problems. ${ }^{189}$ Indeed, requiring the court to try to divine the parties' intent on the question whether they meant to include or exclude scope-limited statutes is itself in tension with the parties' purpose of simplifying the choice-of-law inquiry. The Second Restatement's presumption accomplishes those purposes much more effectively.

More importantly, as discussed above, a geographic scope limitation does not prescribe "non-regulation" as the law of the selected state for cases beyond a statute's geographic scope. Rather, its tells us that, for cases beyond the geographic scope of the statute, the legislator believed cases beyond the statute's scope should be governed by the law of another state. The Third Restatement acknowledges at one point that such provisions reflect deference to the legislative authority of other states, ${ }^{190}$ but it does not recognize what this means: a court seeking to give effect to the legislator's intent in enacting the geographic scope limitation should apply the law of another state to cases beyond the statute's scope. Reading a contractual choice-of-law clause to instruct courts to apply the law of another state to cases beyond a statute's specified geographic scope, however, would be inconsistent with the presumption adopted by both the Second and Third Restatements that choice-of-law clauses do not select the chosen state's whole law. The presumption that choice-of-law clauses do not select a state's whole law makes eminent sense, for the reasons given by both restatements. ${ }^{191}$ But, if the choice-of-law clause does not select the chosen state's whole law, it must

187 Second Restatement, $\ 187(3)$ comment h. To the same effect, see Third Restatement, supra note $20, \S 8.03(2) \&$ comment c.

188 See infra note 201.

189 See, e.g., Cotter v. Lyft, Inc., 60 F. Supp. 3d 1059 (N.D. Cal. 2014); O’Connor v. Uber Techs., Inc., 58 F. Supp. 3d 989, 1005 (N.D. Cal. 2014). See generally Buxbaum, supra note 19, at 398. Indeed, as the Fifth Circuit noted in C.A. May Marine Supply Co. v. Brunswick Corp., " $[n]$ o state intends to govern the transactions of citizens of other states when it establishes laws governing contractual relations between parties." 557 F.2d 1163, 1166-67 (5th Cir. 1977) (emphasis added). If all statutes, and even common-law rules, are subject to implicit geographic scope limitations, the court will have to interpret the law's geographic scope in every case involving a choice-of-law clause. See Barcelo v. Electrolytic Zinc Co of Australasia, 48 C.L.R. 391, 435 (1937) (the parties' stipulation of Victoria law as the applicable law would be "meaningless, unless it implies that the general law of Victoria is to be applied to the transaction without paying regard to the limited territorial application which is a characteristic and inevitable feature of all Victoria law" (emphasis added)). 190 See supra note 108.

191 See supra TAN 187. 
select the law that the chosen state would apply to purely local cases. Those are the only options. As discussed above, a state with a statute having a geographic scope limitation has no law for cases beyond the statute's specified geographic scope. If one understands geographic scope limitations as choice-of-law rules, section 8.03(2)(c) of the Third Restatement establishes the same presumption as section 187(3) of the Second Restatement, and there is no need for Third Restatement section 8.04. ${ }^{192}$

The Third Restatement's approach is admittedly supported by a number of cases that give effect to contractual choice-of-law clauses yet decline to apply scopelimited statutes of the selected state if the case is beyond the statute's specified scope. In addition to being contrary to the parties' likely intent, these decisions overlook the problems discussed in Part IV. Some of these cases conclude that the selected state does have a law for cases beyond the statute's specified geographic scope. In Pengeot Motors of America, Inc. v. Eastern Auto Distributors, Inc., ${ }^{193}$ for example, the court declined to apply New York's statute regulating auto dealers, even though the contract selected New York law as the applicable law, because the statute extended only to dealers that "sell[ or distribute[ in this state." I94 Instead, the court applied New York common law. ${ }^{195}$ But, as discussed in Part IV and V, to subject out-of-state dealers to an anachronistic common-law rule that the state has rejected for in-state dealers would violate a number of constitutional provisions. It is much more likely that the New York legislature intended to leave out-of-state dealers to be governed by the law of the states in which they operate. But that would mean the geographic scope limitation was meant as a choice-of-law rule, and, as such, it was likely meant to be overridden by the choice-of-law clause, as Judge Hall's dissenting opinion persuasively argued. ${ }^{196}$

Other cases do not make clear whether they are interpreting the scope-limited law as leaving excluded cases to be governed by the state's common law, or instead are reading the statute to prescribe non-regulation for cases beyond the statute's specified scope. The Third Restatement relies heavily on Cromeens, Holloman, Sibert Inc. v. AB $V$ olvo, ${ }^{197}$ which involved a franchise contract with a choice-of-law clause selecting

\footnotetext{
192 There may still be a question about whether the choice of law clause is valid, but the black-letter rules for validity of choice-of-law clauses are the same, whether the selected state's law includes a scope-limited statute or not. Compare Third Restatement, supra note 20, \8.04(3) with id. \8.02. The comments to section 8.04 suggests that these rules apply differently where the chosen law includes a statute with a scope limitation if the case falls outside the scope of the statute, but this conclusion appears to be based on the erroneous view that a geographic scope limitation prescribes non-regulation for cases beyond the statute's designated scope.

193892 F.2d 355 (4th Cir. 1989), cert. denied, 497 U.S. 1005 (1990).

194 197-a5, New York's General Business Law, repealed on April 24, 1988.

195892 F.2d at 358.

196 See id. at 360-62.

197349 F.3d 376 (7th Cir. 2003). Third Restatement, supra note 20, \8.04 comment d reporter's note.
} 
Illinois's law as applicable. The Seventh Circuit declined to apply a provision of the Illinois Franchise Disclosure Act (IFDA) to the effect that franchises cannot be terminated without cause on the ground that, by its terms, that Act applies only to franchises within the state of Illinois, and the dispute involved a non-Illinois franchise. ${ }^{198}$ If the court's holding was based on its understanding that Illinois has a law prescribing non-regulation for out-of-state franchises, its holding is problematic for the reasons discussed in Part IV. It would, of course, be reasonable not to apply the IFDA to out-of-state franchises if the consequence is to subject such franchises to the law of another state. As discussed above, that is the likely purpose of the Illinois' geographic scope limitation. But, if so, the geographic scope limitation functions as a choice-of-law rule, and, under both restatements, a contractual choice-of-law clause is presumed to override otherwise applicable choice-of-law rules.

The court in Cromeens upheld the validity of the contract's choice-of-law clause selecting Illinois law as the applicable law, and it accordingly held that the contractual choice of law overrode the possible applicability of the local laws of Texas and Montana (which were similar in content to Illinois's statute). ${ }^{199}$ But it declined to apply Illinois' statute because Illinois' legislature had made it inapplicable to franchises operating in Texas and Montana. Cromeens thus illustrates the perversity of the Third Restatement's approach to geographic scope limitations. Even though all of the relevant states' laws imposed strict limits on the termination of franchises, all of these laws applied to in-state franchises. The parties' selection of the law of a state where the franchise did not operate thus meant that none of these limits could be applied. The Third Restatement embraces this result, viewing the parties' selection of a scopelimited law to a contract beyond the scope of that law as a waiver of otherwise applicable rights. ${ }^{200}$ But it is unlikely that the parties intended the choice of a scopelimited law in these circumstances as a waiver of rights ordinarily protected by the local law of the selected state-particularly when the extraterritorial scope of the law has yet to be specified by the courts. ${ }^{201}$

\footnotetext{
198 Id. at 384.

199 Cromeens, 349 F.3d at 386. The court decided that the law of Maine could be applied because, with respect to Maine's law, the choice-of-law clause was not valid because Maine's law was nonwaivable. Id. at 391.

200 Third Restatement, supra note $20, \mathbb{8} 8.04$ comment d \& Illustration 9. According to this comment, the contractual choice-of-law clause is effective as a waiver if the otherwise applicable law is waivable.

${ }^{201}$ In many of the cases cited by the Third Restatement, the court had to resolve substantial questions about whether the case fell within the scope of the statute under the geographic scope limitation. See, e.g., Gravquick A/S v. Trimble Navigation Int'l Ltd., 323 F.3d 1219, 1223 (9th Cir. 2003); Wright-Moore Corp. v. Ricoh Corp., 908 F.2d 128, 132 (7th Cir. 1990). Since the parties could not have been certain at the time of contracting whether the law of its own force extended to their contract, they could not have intended through their choice-of-law clause to select "nonregulation."
} 
In any event, the precedential value of Cromeens is questionable. The court in Cromeens purported to apply the Second Restatement, but it found section 187(3) inapplicable on the ground that a territorial limitation is not a choice-of-law rule. ${ }^{202}$ In a more recent case, Rabé v. United Airlines, the same court recognized that geographic scope limitations are choice-of-law rules within the meaning of section 187(3), and adopted the analysis defended in this Article. ${ }^{203}$ To be sure, there are a number of other cases that adopt the Cromeens analysis. ${ }^{204}$ All of them are subject to the same criticisms. But there are also a number of cases that adopt the Seventh Circuit's current approach, as reflected in Rabe $e^{205}$ The Third Restatement cites one such case, Hall v. Sprint Spectrum, ${ }^{206}$ but criticizes the decision as "wrongly decided" and "contrary to the

$202 \mathrm{Id}$. at 385. On this point, the court overlooked its own prior decision in Generac Corp. v. Caterpillar Inc., 172 F.3d 971 (7th Cir. 1999), on which it relied for a different point. In an excerpt quoted in Cromeens, the court in Generac specifically characterized a territorial limit as a "particular choice of law rule." Id. at 976 (quoted in Cromeens, 349 F.3d at 386). Even on the point for which the court cited it in Cromeens, Generac did not support the court's holding, as the scope-limited statute in Generac was that of Wisconsin, 172 F.3d at 974, and the contract in that case selected Illinois law, $i d$. at 973. Generac therefore did not give effect to a scope limitation in the face of a contract choosing the law of that state as applicable.

${ }^{203}$ Rabé v. United Airlines, 636 F.3d 866, 871 n.2 (7th Cir. 2011). The Third Restatement treats this as a case in which the court found the scope-limited law applicable because that law was specifically mentioned in the choice-of-law clause, see Third Restatement, supra note $103, \mathbb{S} 8.04$ comment b \& Illustration 6 \& reporter's note. This distorts the court's reasoning. The court in Rabé specifically relied on Second Restatement $\ 187(3)$ and the interpretation of "local law" defended in this Article. Moreover, the court applied the substantive provisions of Title VII, the ADEA, and the Illinois Human Rights Act, notwithstanding those statutes' scope limitations, even though the choice-of- law clause did not mention these statutes. Compare 636 F.2d at 868 (noting that the choice of law clause mentioned the Railway Labor Act), with id. at 870 (holding that the substantive provisions of Title VII, the ADEA, and the IHRA could be applied).

204 See, e.g., Gravquick, 323 F.3d 1219; Bimel-Walroth Co. v. Raytheon Co., 796 F.2d 840, 842-43 (6th Cir. 1986); Cotter v. Parrish, 166 Ill. App. 3d 836, 520 N.E.2d 1172, 1175 (Ill. App. Ct. 1988); Baldewein Co. v. Tri-Clover, Inc., 606 N.W.2d 145, 152-53 (Wis. 2000); Goshen v. Mutual Life Ins., Co. N.Y., 98 N.Y. 2d 314, 324 (N.Y. 2002) Vendetti v. Compass Envtl., Inc., No. 06 CV 3556, 2006 WL 3694852 (N.D. Ill. Dec.14, 2006); Hadfield v. A.W. Chesterton Co., 26 Mass. L. Rep. 101 (Mass. 2009); Risinger v. SOC LLC, 936 F. Supp. 2d 1235, 1249 (D. Nev. 2013); Int'l Profit Assocs., Inc. v. Linus Alarm Corp., 971 N.E.2d 1183, 1190 (Ill. App. Ct. 2012); Cohan v. Medline Indus., Inc., 170 F. Supp. 3d 1162, 1174 (N.D. Ill. 2016); Wooley v. Bridgeview Bank Mortg. Co., LLC, No. 14 C 5757, 2015 WL 327357, at*2 (N.D. Ill. Jan. 23, 2015); Sawyer v. Mkt. Am., Inc., 190 N.C. App. 791, 797, 661 S.E.2d 750, 754 (2008); Taylor v. 1-800-GOT-JUNK?, LLC, 387 F. App’x 727, 729 (9th Cir. 2010): ); Red Lion Hotels Franchising, Inc. v. MAK, LLC, 663 F.3d 1080, 1091 (9th Cir. 2011).

205 See, e.g., Infomax Office Sys, Inc. v. MBO Binder \& Co. of Am., 976 F. Supp. 1247, 1254 (S.D. Iowa 1997) (choice of law clause reflects the parties' intent to have Illinois law applied "as if the parties were within the ambit of Illinois law"); C.A. May, 557 F.2d 1163; Boatland, Inc. v. Brunswick Corp., 558 F.2d 818, 822 (6th Cir. 1977).

206876 N.E.2d 1036 (Ill. 14 App. Ct. 2007). 
overwhelming weight of authority."207 According to this Article's analysis, however, the court's holding in Hall was entirely correct and it is the since-rejected analysis in Cromeens that is wrong. ${ }^{208}$ Many of the cases that apply the Cromeens analysis ${ }^{209}$ simply follow the holdings of prior cases without any independent analysis of the issue. ${ }^{210}$ Others taking this approach do so in dictum or in alternative holdings, ${ }^{211}$ or assume without analysis that choice-of-law clauses select laws subject to their geographic scope limitations. ${ }^{212}$ The cases that adopt the Third Restatement's approach in reasoned decisions $^{213}$ are roughly the same in number as those that adopt the approach defended here. $^{214}$

${ }^{207}$ Restatement (Third) of Conflicts of Laws, supra note 103, \8 8.04 comment b reporter's note. ${ }^{208} \mathrm{An}$ interesting question is raised when a legislature enacts a geographic scope limitation in order to preclude application of its law via a contractual choice-of-law clause. The Wisconsin legislature amended its Fair Dealership Law (FDL) to clarify that it applies only to dealers operating within Wisconsin. Apparently, the legislature specifically wanted to "reverse the effect of the May and Boatman decisions," see supra note 205, which held (correctly) that the FDL was applicable to outof-state dealers by virtue of a contractual choice-of-law clause even if the statute did not apply to such dealers of its own force. See Diesel Service Co. v. Ambac Intern. Corp., 961 F.2d 635, 638 (7th Cir. 1992) (discussing legislative history), overruled on other grounds by Generac, supra note 202. Since the holding of May and Boatman was that the FDL applied under the contract regardless of the legislative intent, it is unclear that an amendment to the statute can override the decision. The rationale of those cases was that any geographic scope limitation is a choice-of-law rule which should be disregarded if the contractual choice-of-law clause selects Wisconsin law. If the point of the amendment was to clarify that Wisconsin doesn't view the scope limitation as a choice-oflaw rule, but instead has a law for out-of-state dealers that, contrary to its law for in-state dealers, permits unfair dealing, the statute is constitutionally problematic for the reasons discussed in Part IV. Since even the Third Restatement acknowledges that the parties may select a law that does not of its own force apply to the case, it is unclear what the legislative amendment accomplishes.

${ }^{209}$ In addition to the cases discussed here, the Third Restatement claims support from Generac as well as Avery v. State Farm Mut. Auto. Ins. Co., 835 N.E.2d 801 (2005). As discussed above, however, Generac supports this Article's interpretation of Second Restatement $\int 187(3)$. See supra note 202. Avery does not appear to have involved a contractual choice-of-law clause.

210 See Cohan, 170 F. Supp. 3d 1162; Wooley, 2015 WL 327357; Sawyer, 190 N.C. App. 791; Hadfield, 26 Mass. L. Rep. 101; Risinger, 936 F. Supp. 2d 1235; Taylor, 387 F. App’x 727.

211 Gravquick, 323 F.3d 1219 (dictum); Cotter, 166 Ill. App. 3d 836 (alternative holding).

212 Vendetti, 2006 WL 3694852; Bimel-Walroth, 796 F.2d 840; Hadfield, 26 Mass. L. Rep. 101; Red Lion, 663 F.3d 1080; Baldewein, 606 N.W.2d 145; ); Goshen, 98 N.Y. 2d 314.

213 Pengeot, 892 F.2d 355; Cromeens, 349 F.3d 376; Int'l Profit Assocs., 971 N.E.2d 1183.

${ }^{214}$ Rabé v. United Airlines, 636 F.3d 866 (7th Cir. 2011); C.A. May Marine Supply Co. v. Brunswick Corp, 557 F.2d 1163 (5th Cir. 1977); Boatland, Inc. v. Brunswick Corp., 558 F.2d 818, 822 (6th Cir. 1977); Infomax Office Sys, Inc. v. MBO Binder \& Co. of Am., 976 F. Supp. 1247, 1254 (S.D. Iowa 1997); Mon-Shore Mgmt. Inc. v. Family Media Inc. 584 F. Supp. 186 (S.D.N.Y. 1984); Hall v. Spring Spectrum, 876 N.E.2d 1036 (Ill. 14 App. Ct. 2007); Dep’t of Motor Vehicles v. MercedezBenz of N. Am. Inc. 408 So. 2d 627 (Fla. App. 1981) Diesel Injection Serv. v. Jacob Vehicle Equip., No. CV 980582400S, 1998 WL 950986, (Conn. Super. Ct. Dec. 4, 1998) 
In any event, when faced with precedent that is "inappropriate or inconsistent with the law as a whole," a Restatement is "not compelled to adhere to . . . 'a preponderating balance of authority' but is instead expected to propose the better rule and provide the rationale for choosing it." ${ }^{, 15}$ For the reasons set forth in this Article, the Second Restatement's position that contractual choice-of-law clauses are presumed to select the chosen state's local law, meaning the law that it applies to purely local cases, is the better rule. ${ }^{216}$ The increasing number of cases that blindly follow the decisions adopting the mistaken approach of Cromeens makes it all the more urgent for the Third Restatement to correct this error.

\section{B. Renvoi}

Conflict of laws scholars have been debating renvoi for centuries. This Article will not resolve those debates, but the Article's thesis does have implications for some aspects of current debates. As noted, both Restatements prohibit renvoi in most cases: they provide that, when the choice-of-law rules set forth in the restatements instruct the court to apply the law of another state, the court is (with limited exceptions) supposed to apply that state's law exclusive of its choice-of-law rules. ${ }^{217}$ But, because of their differing understandings of what counts as a choice-of-law rule, the two restatements contain different instructions to courts regarding geographic scope limitations. The Second Restatement instructs the courts to apply another state's law exclusive of geographic scope limitations, ${ }^{218}$ while the Third Restatement instructs them to give effect to geographic scope limitations. ${ }^{219}$

As this Article has sought to show, geographic scope limitations in statutes are best understood as choice-of-law rules. They do not reflect the legislature's view that the substantive law it enacted in the statute is inappropriate or unsuitable for cases falling outside the statute's specified scope. Rather, they reflect the legislator's accommodation of the possibly different substantive preferences of other states. The legislature is not prescribing a different substantive rule for excluded cases; it is instead leaving such cases to be governed by the substantive rules enacted by other states. If these provisions are regarded as choice-of-law provisions, then the courts of State B should disregard the geographic scope limitations of a State A statute if State B's choice-of-law rules select the law of to State A as the applicable law and State B's

215 The American Law Institute, A Handbook for ALI Reporters and Those Who REVIEW THEIR WORK, at 5 (2015).

216 See Diesel Injection Serv., 1998 WL 950986, at *5 (recognizing that more cases follow the Cromeens approach, but noting that most of these cases are unreasoned and conclusory, and adopting instead the "more persuasive" analysis of the C.A. May decision, supra note 189).

217 See supra TAN 23, 28.

218 See supra TAN 23-27.

219 See supra TAN 28-30. 
choice-of-law rules prohibit renvoi. Under a proper reading of the provisions of the Second and Third Restatements, both of which permit renvoi only in narrow circumstances, the scope limitations of State A's statute should ordinarily be disregarded by the court if the choice-of-law rules of the respective restatements select the law of State A as the applicable law.

Similarly, the Rome Regulations establish choice-of-law rules binding on E.U. Member States and prohibit renvoi except when it is expressly permitted. ${ }^{220}$ Consistent with the Third Restatement's approach, some European scholars have opined that this section does not prohibit the application of geographic scope limitations. Thus, Professor Rödl has written that "[a] country's rules of private international law must be distinguished from spatial or personal limitations to the substantive rules of the law of a country that are applicable according to the present Regulation's conflicts rules. Article 24 only excludes resort to the former kind of rules and does not interfere with the latter.",221

The authority cited by Rödl for this conclusion is equivocal, however. Rödl relies in part on the Dicey, Morris \& Collins treatise, discussed above. ${ }^{222}$ As we saw, however, this treatise recognizes that some geographic scope provisions are unilateral choice-of-law rules. ${ }^{223}$ Moreover, the treatise recognizes that no one has yet to articulate a satisfactory test for distinguishing between unilateral choice-of-law rules and self-limiting provisions. ${ }^{224}$ It is thus not a promising source for the interpretation of the Rome Regulation that Rödl defends. ${ }^{225}$

The other authority cited by Rödl is British scholar Peter Kaye. Commenting on Article 15 of the Rome Convention, which excludes renvoi in language substantively

\footnotetext{
220 See supra note 8.

221 GRAlF-PETER CALlies, ED., ROME REgulations: COMMENTARY ON THE EUROPEAN RuLES OF THE CONFLICTS OF LAWS 316 (2011).

222 See supra TANs 41-48.

223 See supra TANs 42-45.

224 See supra at TAN 48.

225 Similarly, Professor Dickinson's treatise on the Rome II Regulations states that "the exclusion of a country's rules of private international law does not prevent the application of so-called 'selflimiting provisions' in legislation.” ANDREW DiCKINSON, THE ROME II REGULATION: THE LAW Applicable to Non-Contractual Obligations 138 (2010) (citing Dicey, Morris and Collins treatise). Professor Dickinson explains that, when a state is faced with a self-limited statute, it will give effect to the limitation and as a result apply "a (normally more general) rule of local origin." The problems with understanding a geographic scope limitation as leaving cases beyond the statute's specified scope to be governed by a common-law rule that the legislature has deemed inadequate for local cases has already been discussed.
} 
identical to the provisions of the Rome Regulations, ${ }^{226}$ Kaye writes that "it is unclear whether excluded 'private international law' under Article 15 is to be taken to include" geographic scope limitations, but endorses the view that such rules should be regarded as falling outside the exclusion on the ground (for which he supplies no citation) that "'renvoi' and 'private international law' are principally concerned with the selection of potentially applicable laws, rather than with the imposition or spatial limitation of operation of one particular legal norm or statute." 227 But, as we have seen, these spatial limitations are concerned with the question of which law should apply to the subject matter of the statute. In any event, a source that concedes that the issue is unclear is also not strong authority for Rödl's preferred interpretation.

Ultimately, Kaye's conclusion seems to be based on a policy rationale. Kaye argues that "[i]t would seem strange indeed if, by virtue of Article 15, English courts were to find themselves having to apply rules on restraint of trade under English applicable law, in relation to contracts essentially affecting French, not English, markets." 228 But it would be equally strange to apply England's preexisting commonlaw rules to such a contract, which is what some like-minded commentators say the Rome Regulations require. ${ }^{229}$ Kaye provides a valid policy reason for making French law, rather than English law, applicable to contracts mainly affecting French markets. If the Rome Convention does make English law applicable to such a contract, and English law did include a scope limitation, Kaye's policy concerns would support an argument that renvoi should be permitted. Unfortunately, the Rome Regulations (and before that the Rome Convention) appear to foreclose this argument.

Because the Third Restatement has not been finalized, there is still room to argue that it should permit renvoi in a greater number of cases than the current draft does. This Article's thesis would support the argument that renvoi should be permitted when the state whose law is applicable under otherwise applicable choice-of-law rules has enacted a statute on the subject and the statute includes a geographic scope limitation. If the case at hand falls outside the statute's specified scope, the case is one that the enacting state's legislature has concluded should be governed by the law of another state. The enacting state, in other words, has concluded that, in such a case, it will defer to the substantive law of another state. If the Third Restatement's otherwise applicable choice-of-law rules select the law of the enacting state as the applicable law, the Restatement should consider permitting the court to reconsider the

226 Article 15 provides that "[t]he application of the law of any country specified by this Convention means the application of the rules of law in force in that country other than its rules of private international law

227 Peter Kaye, The New Private International Law of Contract OF The European COMMUNITY at 343 (1993).

$228 \mathrm{Id}$.

229 See DiCKINSON, supra note 225. 
choice-of-law question and, consistent with the legislator's decision to defer to another state, consider applying its own law, or the law of a third state, instead.

The Second Restatement prohibits renvoi in most cases. Thus, if the Second Restatement's choice-of-law rules select the law of a state that has a statute on the subject with a geographic scope limitation, it will apply the substantive law of that state disregarding the geographic scope limitation. My analysis here suggests that the Second Restatement's prohibition of renvoi in such cases is questionable. However, the Second Restatement's choice-of-law rules are so malleable and indeterminate that a court from a state that follows the Second Restatement could easily - and indeed, probably should - take the geographic scope limitation into account in making the antecedent determination of which state's law applies. The Second Restatement's general test for choice-of-law is that the law of the state with the "most significant relationship" to the relevant issue applies. ${ }^{230}$ In determining which state has the "most significant relationship" to an issue, the Second Restatement lists many "choice of law principles" to be taken into account. Among these are "the relevant policies of other interested states and the relevant interests of those states in the determination of the particular issue." 231 If a state has a statute addressing that issue, and the statute has a geographic scope limitation indicating that the statute does not extend to the case at hand, the court can properly conclude that the state does not have a strong interest in the determination of that issue in the case at hand.

The Third Restatement's choice-of-law sections have yet to be adopted, but the reporters aim to propose choice-of-law rules that are less malleable and more determinate than those of the Second Restatement. ${ }^{232}$ If more determinate choice-oflaw rules are adopted, as they were in the Rome Regulations, the need for a more nuanced approach to renvo $i$ would be greater. Permitting renvoi in general may not be desirable, but permitting it when the otherwise applicable law includes a geographic scope limitation might be appropriate. Such provisions reveal the enacting legislature's choice-of-law preferences. If interpreted properly, they will lead that state's courts to apply the law of another state. Recognizing an exception to the general prohibition of renvoi for cases involving geographic scope limitations might somewhat undercut the aim of having reasonably determinate choice-of-law regime that affords litigants and courts a significant measure of certainty and predictability. If so, the Restatement would have to weigh its desire to have determinate rules against its desire to give effect to the enacting state's choice-of-law preferences and its interest in achieving a uniformity of result as between the forum state and the enacting state.

\footnotetext{
230 See, e.g., Second Restatement, \145.

231 Id. $\int 6(2)(\mathrm{c})$.

232 See Kermit III Roosevelt \& Bethan Jones, What a Third Restatement of Conflict of Laws Can Do, 110 AM. INT'L L. UNBOUND 139, 141 (2016).
} 


\section{CONCLUSION}

This Article has shown that a provision specifying that a statute extends to persons or conduct having certain connections to the state is properly treated as a choice-of-law rule. Such a provision does not reflect the legislature's view that the substantive provisions of the statute are inappropriate for cases falling outside the statute's geographic scope. Rather, it reflects the legislature's willingness to accommodate the legislative prerogatives of other states, whose legislatures may have a different view regarding the proper substantive rule to govern the particular subject. For this reason, contrary to the position taken by the Third Restatement of Conflict of Laws and some scholars, courts of other states are not obligated to give effect to the geographic scope provision. A state that applies another state's law to cases beyond the law's scope as specified in a geographic scope provision does not evince disrespect for the preferences of the enacting legislature. It instead declines the other state's offer to defer to it. Nor does a state that fails to give effect to a sister state's geographic scope limitation violate the Full Faith and Credit Clause. Instead, it gives its sister state's law more faith and credit than the sister state's legislature has asked for.

The recognition that a geographic scope limitation is a conflict of laws rule has implications for two important issues currently being debated by the American Law Institute in the context of its elaboration of a Third Restatement of Conflict of Laws. First, it strongly supports retaining the Second Restatement's provision establishing a presumption that a contractual choice of-law clause selects a state's law exclusive of any geographic scope limitations. Second, it suggests that the Restatement should permit courts greater freedom to engage in renvoi, at least to the extent of treating another state's geographic scope limitation as an invitation to apply the law of another state to cases beyond the statute's specified scope. 